\title{
Arabidopsis cytochrome P450s through the looking glass: a window on plant biochemistry
}

\author{
Mary A. Schuler · Hui Duan · Metin Bilgin • \\ Shahjahan Ali
}

Received: 20 April 2006/ Accepted: 3 October 2006/Published online: 24 November 2006

(C) Springer Science+Business Media B.V. 2006

\begin{abstract}
Annotation of the genome sequence of Arabidopsis thaliana has identified a diverse array of 245 full-length cytochrome P450 monooxygenase (P450) genes whose known functions span the synthetic gamut from critical structural components (phenylpropanoids, fatty acids, sterols) to signaling molecules (oxylipins, brassinosteroids, abscisic acid, gibberellic acid) and defense compounds (alkaloids, terpenes, coumarins). Numerous others in this collection mediate functions that are now being addressed using microarray and oligoarray technologies, molecular modeling, heterologous expression and insertional mutageneses. Profilings of their constitutive and inducible transcript levels have begun to cluster P450s that are likely to mediate tissue-specific and stress-specific monooxygenations. With proper appreciation of the high identities that exist among some of the most recently duplicated P450 sequences, these studies have begun to differentiate $\mathrm{P} 450$ s with early response functions leading to production of stress signaling molecules and late response functions leading to the synthesis of protective compounds. Further func-
\end{abstract}

M. A. Schuler $(\bowtie) \cdot$ H. Duan · M. Bilgin .

S. Ali

Department of Cell and Developmental Biology,

University of Illinois, 190 ERML, 1201 W. Gregory

Drive, Urbana, IL 61801, USA

e-mail: maryschu@uiuc.edu tional analyses of these P450 sequences with perspectives on their response profiles rely on a variety of theoretical modeling and experimental approaches that can ultimately be tied to the transcriptional profiles and genetic mutants. This review surveys historical and evolutionary aspects of P450 studies, expression variations among Arabidopsis $\mathrm{P} 450$ loci, catalytic site regions critical for substrate recognition and, finally, genetic mutations/disruptions that can ultimately tie biochemical reactions to physiological functions in a manner not yet possible in most other organisms.

Keywords Arabidopsis - Cytochrome P450 monooxygenases $\cdot$ Microarrays $\cdot$ Functional genomics

\section{Historical and evolutionary perspectives}

The view through the window starts with a single cytochrome P450 monooxygenase (P450) identified and cloned in a long series of plants, beginning with Jerusalem artichoke (Benveniste et al. 1977; Gabriac et al. 1991), pea (Benveniste et al. 1978; Stewart and Schuler 1989) and eventually extending to Arabidopsis thaliana (mouse ear cress) (Mitzutani et al. 1997). In retrospect, its discovery was not surprising, since this ubiquitous $\mathrm{P} 450$ protein, dubbed $t$-cinnamic acid hydroxylase $(t-\mathrm{CAH})$ and cinnamic 4-hydroxylase $(\mathrm{C} 4 \mathrm{H})$ by 
various sets of investigators, exists as the one most abundant and constitutively expressed monooxygenase present in all plants. Mediating a critical reaction in the phenylpropanoid pathway, this particular P450 was shown to control flux from $t$-cinnamic acid ( $t$-CA), a phenylalanine derivative, into a collection of branched pathways leading to the synthesis of lignin, flavonoids, anthocyanins and phytoalexins. Representative in its catalytic core of a superfamily of P450 proteins capable of incorporating oxygen into aliphatic and aromatic molecules using electron transfer partners that are either membrane-bound (NADPH-dependent P450 reductase and cytochrome $b_{5} /$ cytochrome $b_{5}$ reductase for ER-localized P450s) or soluble (ferrodoxin and ferrodoxin reductase for chloroplast $\mathrm{P} 450 \mathrm{~s}$ ), this protein was initially purified because of its high constitutive abundance. Later, it became the standard against which other plant $\mathrm{P} 450$ proteins were measured because it was recognized as a highly selective and essential enzyme capable of yielding only $p$-coumaric acid, the precursor needed for subsequent branches in the phenylpropanoid pathway.

From a genomics perspective, this particular P450 and its transcripts represent just one of the many P450s that exist in plants. Annotations in the completely sequenced genomes of Arabidopsis and Oryza sativa (rice) have indicated that 245 full-length genes with 27 pseudogenes are contained in the Arabidopsis genome (Paquette et al. 2000; Werck-Reichhart et al. 2002; Schuler and Werck-Reichhart 2003) and that 334 full-length genes, 7 unresolved partial genes and 100 pseudogenes are contained in the Oryza genome (Nelson et al. 2004 and more recent annotations). Reflecting a highly diverse set of reactive sites, the $\mathrm{P} 450$ proteins existing in each of these species are encoded by a divergent gene superfamily that maintains significant conservation in secondary and tertiary structures with relatively low levels of primary sequence conservation. Amino acid conservations among the most divergent members of this superfamily in these species are typically in the range of $15-20 \%$ and sometimes as low as 14\% (as between Arabidopsis CYP707A2 and rice CYP723A2). Analysis of $\mathrm{P} 450$ sequences in many different phyla has indicated that the most diagnostic signature motif for a $\mathrm{P} 450$ protein is a short sequence (F-G-R-C-G) surrounding the heme cysteine ligand positioned approximately 55 a.a. from the C-terminus (Nelson et al. 1993, 1996). But, even this signature is not strictly conserved in all members of the P450 superfamily; some of the most divergent P450s (e.g., allene oxide synthases (AOS), hydroperoxide lyases (HPL)) contain only three of these conserved amino acids.

Within any one organism such as Arabidopsis, the superfamily of P450 sequences has evolved to contain a spectrum of families that differ substantially in their coding sequences, intron positions and regulatory elements. To avoid the acronyms used earlier that designated P450s according to their substrate and/or historical source, a universal nomenclature system evolved that annotates P450 sequences with a CYP (CYtochrome P450) designator followed by numerical and alphabetic characters identifying family and subfamily groupings based on identities in their amino acid sequence (Nelson et al. 1993, 1996). In this, the most highly related monooxygenase proteins are grouped into gene families designated with numbers (CYP1, CYP2, etc.) indicating sequences sharing greater than $40 \%$ amino acid identity with subfamilies designated with alphabetical characters (A, B, C, etc.) indicating sequences sharing greater than $55 \%$ amino acid identity and individual loci designated with additional numbers following the subfamily designation (CYP1A1, CYP1A2, CYP1A3, etc.). In organisms where it is not yet clear if closely related sequences sharing more than $97 \%$ amino acid identity are derived from different loci, individual sequences are designated as allelic variants (v1, v2, etc.) following the locus designation. In organisms with complete genomic information (e.g., Arabidopsis, Oryza), closely related sequences sharing this level of identity are designated as independent loci unless they represent mutants or ecotype variants of a single locus.

Current Arabidopsis P450 annotations available at two evolving databases (http://Arabidopsis-P450.biotec.uiuc.edu; http://www.p450.kvl.dk// p450.shtml) indicate that, among the $44 \mathrm{P} 450$ families and 69 subfamilies represented in the Arabidopsis genome, several single P450 gene 
families exist. These include CYP73A5 ( $t$-CAH/ $\mathrm{C} 4 \mathrm{H}$ ) in phenylpropanoid synthesis (Mitzutani et al. 1997), CYP75B1 (F3'H) in flavonoid/anthocyanin synthesis (Schoenbohm et al. 2000), CYP701A3 (ent-kaurene oxidase) in gibberellin synthesis (Helliwell et al. 1998, 1999), CYP734A1 (brassinolide 26-hydroxylase) in brassinosteroid degradation (Neff et al. 1999; Turk et al. 2003) and a collection of highly divergent genes that represent the first and sometimes sole members of new P450 families and subfamilies (e.g., CYP93D1, CYP711A1, CYP718A1, CYP720A1, CYP721A1, etc.). Duplication and diversification in other families has resulted in an array of other subfamilies containing between two members (CYP51G, CYP79F, CYP85A, etc.), 16 members (CYP71A) and 37 members (CYP71B).

Comparison with the array of $\mathrm{P} 450$ loci existing in rice has highlighted a number of lineagespecific P450 families maintained and lost during evolution of these monocot (rice) and dicot (Arabidopsis) species (Nelson et al. 2004). Arabidopsis $\mathrm{P} 450$ families clearly absent from the rice include CYP82, CYP83, CYP702, CYP705, CYP708, CYP712, CYP716, CYP718 and CYP720 but, with the exception of CYP705, all of these correspond to single gene or small multigene $\mathrm{P} 450$ families (2-6 members) that may mediate functions particular to Arabidopsis and/or functions replaceable by more divergent enzymes existing in rice. Interestingly, five of these "Arabidopsis-specific" families are grouped with the CYP85 clan, a phylogenetically larger grouping that was originally designated for its members mediating the modification of sterols and cyclic terpenes in brassinosteroid (BL), abscisic acid (ABA) and gibberellic acid (GA) biosynthesis (Nelson 1999). Others, such as the CYP82 and CYP83, appear to be divergent offshoots of the prolific CYP81 and CYP71 families, respectively, whose members have not been extensively characterized at this time.

The number and diversity of these many P450 loci provide special challenges in characterizing their expression patterns and physiological functions that are discussed further in this review. Even considering these challenges, the breadth of their biochemical activities and location in many essential plant pathways indicate that they can serve as important reporters for visualizing the intricacies of plant biochemistry and its integrated network of interacting pathways. Their role as reporters is especially evident when one considers that many of the proteins within this gene family exist at critical nodes in pathways responsible for synthesizing hormones (GA, BL, ABA, IAA) and plant signaling molecules (jasmonic acid (JA), salicylic acid (SA)), at branchpoints in pathways leading to the synthesis of plant defense molecules (lignin, flavonoids, phytoalexins) and at the termini of these pathways where, as targets for these defense signaling cascades, they are responsible for the direct synthesis of defense molecules. With their clear roles in the synthesis of hormones and signaling molecules, their networking exemplifies the range of integrated events occurring at the level of signal transduction especially as related to stress. With their existence in at least two different cellular compartments, the endoplasmic reticulum and chloroplasts, their networking also exemplifies the types of integration needing to occur between these cellular compartments.

\section{Subcellular locations}

With so many loci in this gene family, any categorization process that is aimed at grouping those with similar functions (e.g., subcellular location, tissue distributions, transcriptional response times, range of inducers, enzymatic activities) has potential for distinguishing one P450 protein and its corresponding locus from the next and limiting the range of functions predicted for each. In terms of subcellular location, it is clear that most of the Arabidopsis P450s are targeted to the endoplasmic reticulum (ER) using an aminoterminal signal sequence of 25-30 amino acids that, after insertion in this membrane, is not cleaved from the initial translation product. Positioned in this manner, the remainder of their structure remains on the cytoplasmic side of the membrane situated in proximity to ER-anchored NADPH P450 reductases that act as their electron transfer partners. A significantly smaller set of Arabidopsis P450s are targeted to chloroplasts using longer and more hydrophilic amino-terminal 
transit sequences. Analysis of amino-terminal sequences using the ChloroP program (Emanuelsson et al. 1999; http://www.cbs.dtu.dk/services/ ChloroP) has identified a total of 42 Arabidopsis $\mathrm{P} 450$ s that, according to these algorithms, are predicted to be targeted to the chloroplast because they contain a putative cleavage site for a chloroplast transit sequence (Table 1). Closer inspection of the positions of prolines, serines and threonines within these putative transit sequences, which vary in length from 10 to 97 amino acids, indicates that many of these contain clustered prolines approximately 30-35 amino acids from their aminoterminus, are not especially rich in Ser/Thr in their preceding amino acids and have sequence compositions more like endoplasmic reticulum-localized P450s. Elimination of these sequences and retention of those containing substantial numbers of Ser and Thr $(>14 \%)$ in their amino-terminal sequences suggest that only 11 of those predicted to be chloroplast-localized by ChloroP may contain actual chloroplast targeting sequences (underlined in Table 1). Of these, CYP74A1 (AOS in JA synthesis), CYP74B2 (HPL in hexenal synthesis), CYP86B1 (undefined function), CYP97A3 (carotene $\beta$-hydroxylase in carotenoid synthesis), CYP97C1 (carotene $\varepsilon$-hydroxylase in carotenoid synthesis) and CYP701A3 (kaurene oxidase in GA synthesis) have actually been identified as chloroplast-localized (double asterisks in Table 1) (Froehlich et al. 2001; Helliwell et al. 2001; Watson et al. 2001; Tian et al., 2004; Kim and DellaPenna 2006). But, the final destinations of these differ considerably with one (CYP74A1) localized to the inner chloroplast membrane facing the stroma, another (CYP74B2) localized in the outer chloroplast membrane facing the intermembrane space, two (CYP86B1, CYP701A3) localized to the outer chloroplast membrane facing the cytoplasm and the remaining two (CYP97A3, CYP97C1) targeted to undefined locations in the chloroplast. Comparisons of the six proteins known to be chloroplast targeted indicate that the amino-termini of the four targeted into the chloroplast have 3-8 prolines scattered among the serines and threonines of their first 30 amino acids and the two targeted to the outside of the chloroplast have $0-1$ prolines in their first 40 amino acids and $16-33 \%$ Ser/Thr in their first 30 amino acids. Evaluation of the others underlined in the ChloroP list (not eliminated based on the presence of a proline hinge) against these standards suggests that CYP78A5, CYP94B1, CYP94D1 and CYP97B3 all have features of proteins targeted into the chloroplasts. Further analysis of the remaining Arabidopsis $\mathrm{P} 450$ s against this more elaborate set of criteria indicates that CYP72A8 and CYP72A9 lack proline clusters but have high Ser/Thr contents as do several targeted to the outside of the chloroplast.

Two of those in the chloroP list, CYP79B2 and CYP79B3 involved in the synthesis of glucosinolates that are thought to be chloroplast-localized (described further in Nafisi et al. (2006) in this volume) display activities when expressed in E. coli and reconstituted with purified sorghum or rat microsomal $\mathrm{P} 450$ reductases (Hull and Celenza 2000; Mikkelsen et al. 2000). Others predicted by chloroP to be chloroplast-localized, such as CYP707A1 and CYP707A3 mediating ABA degradation (Kushiro et al. 2004; Saito et al. 2004), have been expressed in yeast and insect cells in the presence of the ER-localized Arabidopsis $\mathrm{P} 450$ reductase and are likely to be ER-localized. The lengths of their amino-terminal sequences and their lower Ser/Thr contents are more consistent with this localization. The range of $\mathrm{P} 450$ s predicted to be targeted to the chloroplasts by the TargetP program (Table 1) (Emanuelsson et al. 2000) overlaps to some extent those predicted by the ChloroP program but some notable omissions occur. Among these, the omission of CYP86B1 and CYP701A3 known to be targeted to the exterior surface of the chloroplast suggests that TargetP predictions are less useful in predicting proteins targeted to the outer chloroplast membrane.

Although no plant P450s have yet been localized to mitochondria, as is the case for some mammalian $\mathrm{P} 450$ s, it remains conceivable that some plant $\mathrm{P} 450$ s are targeted to this organelle. TargetP predicts that as many as fifteen Arabidopsis $\mathrm{P} 450 \mathrm{~s}$ might be targeted to this organelle. But, further analyses of these indicate that two are also predicted to be chloroplast targeted by the alternate ChloroP program (blue in Table 1), twelve have amino-terminal sequence compositions 
Table 1 P450s with chloroplast or mitochondiral targeting signals

\begin{tabular}{|c|c|c|c|c|c|}
\hline \multicolumn{6}{|c|}{ Mitochondrial-localized P450s predicted by TargetP } \\
\hline P450 & protein length & mTP score & mTP length & $\mathrm{S} / \mathrm{T} \%$ & proline hinge \\
\hline CYP71A18 & 498 & 0.199 & 64 & 17.2 & $\mathrm{Y}$ \\
\hline CYP71B9 & 498 & 0.279 & 99 & 15.0 & $\mathrm{Y}$ \\
\hline CYP71B36 & 496 & 0.238 & 34 & 15.0 & $\mathrm{Y}$ \\
\hline CYP71B37 & 496 & 0.486 & 26 & 7.7 & $\mathrm{Y}$ \\
\hline CYP75B1 & 513 & 0.322 & 57 & 12.3 & $\mathrm{Y}$ \\
\hline CYP76C4 & 511 & 0.264 & 114 & 7.9 & $Y$ \\
\hline CYP86A4 & 514 & 0.46 & 73 & 9.6 & $Y$ \\
\hline CYP87A2 & 473 & 0.618 & 107 & 12.3 & $Y$ \\
\hline CYP89A2 & 506 & 0.365 & 25 & 12.0 & $Y$ \\
\hline CYP90A1 & 473 & 0.595 & 106 & 12.3 & $Y$ \\
\hline CYP90C1 & 524 & 0.633 & 49 & 6.1 & ambiguous \\
\hline CYP97B3 & 577 & 0.496 & 42 & 42.9 & $\mathrm{~N}$ \\
\hline CYP98A9 & 498 & 0.29 & 51 & 9.8 & $Y$ \\
\hline CYP704B1 & 524 & 0.505 & 67 & 11.9 & ambiguous \\
\hline CYP710A3 & 479 & 0.653 & 50 & 6.0 & $\mathrm{Y}$ \\
\hline \multicolumn{6}{|c|}{ Red colored ones are predicted as chloroplast-localized P450s in ChloroP } \\
\hline \multicolumn{6}{|c|}{ Chloroplast-localized P450s predicted by ChloroP } \\
\hline P450 & protein length & cTP score & cTP Length & $\mathrm{S} / \mathrm{T} \%$ & proline hinge \\
\hline CYP51G2 & 489 & 0.519 & 55 & 16.4 & $\mathrm{Y}$ \\
\hline CYP71A16 & 497 & 0.512 & 79 & 13.9 & $\mathrm{Y}$ \\
\hline CYP71A19 & 490 & 0.504 & 80 & 17.5 & $\mathrm{Y}$ \\
\hline CYP71A20 & 495 & 0.508 & 55 & 18.0 & $Y$ \\
\hline CYP71A24 & 486 & 0.508 & 78 & 11.5 & $Y$ \\
\hline CYP71A28 & 488 & 0.531 & 83 & 20.5 & $Y$ \\
\hline CYP71B11 & 496 & 0.502 & 75 & 16.0 & $Y$ \\
\hline CYP71B13 & 492 & 0.502 & 55 & 10.9 & $Y$ \\
\hline CYP71B14 & 492 & 0.509 & 75 & 13.3 & $Y$ \\
\hline$\underline{\mathrm{CYP} 74 \mathrm{~A} 1^{* *}}$ & 517 & 0.535 & 32 & 21.9 & $\mathrm{~N}$ \\
\hline$\underline{\text { CYP74B2 }}^{* *}$ & 484 & 0.566 & 29 & 31.0 & $\mathrm{~N}$ \\
\hline CYP76C2 & 512 & 0.512 & 30 & 16.7 & $Y$ \\
\hline CYP76C3 & 506 & 0.567 & 81 & 19.8 & $Y$ \\
\hline CYP76C4 & 511 & 0.517 & 34 & 26.5 & $Y$ \\
\hline CYP76C6 & 505 & 0.518 & 25 & 12.0 & $Y$ \\
\hline CYP76C7 & 498 & 0.52 & 68 & 14.7 & $Y$ \\
\hline CYP76C8P & 470 & 0.508 & 22 & 13.6 & \\
\hline CYP77A4 & 512 & 0.518 & 30 & 13.3 & $Y$ \\
\hline CYP77A6 & 513 & 0.52 & 33 & 27.3 & $Y$ \\
\hline$\underline{\text { CYP78A5 }}$ & 517 & 0.509 & 19 & 15.8 & $\mathrm{~N}$ \\
\hline CYP78A9 & 534 & 0.521 & 77 & 19.5 & $Y$ \\
\hline CYP79АЗР & 532 & 0.504 & 19 & 21.1 & \\
\hline CYP79B2 & 541 & 0.521 & 14 & 57.1 & $\mathrm{Y}$ \\
\hline CYP79B3 & 566 & 0.557 & 70 & 25.7 & $Y$ \\
\hline CYP79C1 & 545 & 0.506 & 68 & 10.3 & $\mathrm{Y}$ \\
\hline
\end{tabular}

more reminiscent of ER-localized P450s (e.g., 2-5 prolines in a short "hinge" region separating the signal sequence from the body of the protein) and two have ambiguous proline-hinge regions. Thus, it is unclear whether any of these Arabidopsis $\mathrm{P} 450$ s are mitochondrially targeted.

\section{Transcripts represented in databases}

Our detailed BLAST analyses (Altschul et al.1990) of available full-length cDNA and EST collections for the 272 Arabidopsis P450 genes and pseudogenes have identified 438 full-length P450 cDNAs in 
Table 1 continued

\begin{tabular}{|c|c|c|c|c|c|}
\hline CYP79C2 & 530 & 0.515 & 29 & 27.6 & $\mathrm{Y}$ \\
\hline CYP81D3 & 501 & 0.502 & 97 & 15.5 & $\mathrm{Y}$ \\
\hline CYP81D11 & 502 & 0.506 & 82 & 13.4 & $\mathrm{Y}$ \\
\hline CYP84A1 & 520 & 0.515 & 64 & 20.3 & $\mathrm{Y}$ \\
\hline$\underline{\text { CYP86B1 }}^{* *}$ & 560 & 0.504 & 17 & 23.5 & $\mathrm{~N}$ \\
\hline СУР89АЗ & 513 & 0.514 & 10 & 10.0 & $\mathrm{Y}$ \\
\hline CYP89A7 & 511 & 0.512 & 73 & 12.3 & $\mathrm{Y}$ \\
\hline CYP94B1 & 510 & 0.517 & 66 & 16.7 & $\mathrm{~N}$ \\
\hline$\underline{\text { CYP94D1 }}$ & 498 & 0.525 & 60 & 16.7 & $\mathrm{~N}$ \\
\hline CYP94D2 & 499 & 0.502 & 78 & 14.1 & $\mathrm{~N}$ \\
\hline$\underline{\text { CYP97A3 }}^{* *}$ & 589 & 0.555 & 28 & 25.0 & $\mathrm{~N}$ \\
\hline CYP97B3 & 576 & 0.524 & 82 & 22.2 & $\mathrm{~N}$ \\
\hline$\underline{\text { CYP97C1 }}^{\text {** }}$ & 576 & 0.579 & 36 & 38.9 & $\mathrm{~N}$ \\
\hline$\overline{\mathrm{CYP701A}}^{\star *}$ & 509 & 0.545 & 28 & 14.3 & $\mathrm{~N}$ \\
\hline CYP705A28 & 524 & 0.513 & 31 & 12.9 & $Y$ \\
\hline СҮР705АЗ0 & 523 & 0.518 & 34 & 11.8 & $Y$ \\
\hline CYP707A1 & 457 & 0.502 & 80 & 15.0 & $\mathrm{Y}$ \\
\hline CYP707A3 & 469 & 0.512 & 80 & 16.3 & $\mathrm{Y}$ \\
\hline CYP712A2 & 528 & 0.534 & 55 & 18.2 & $\mathrm{Y}$ \\
\hline \multicolumn{6}{|c|}{ Blue colored ones are also predicted as chloroplast-localized by TargetP } \\
\hline \multicolumn{6}{|c|}{ Red colored ones are predicted as mitochondria-localized P450s in TargetP } \\
\hline \multicolumn{6}{|c|}{${ }^{\star *}$ Experimentally confirmed as chloroplast-localized } \\
\hline \multicolumn{6}{|c|}{ Chloroplast-localized P450s predicted by TargetP } \\
\hline P450 & protein length & cTP score & cTP Length & $\mathrm{S} / \mathrm{T} \%$ & proline hinge \\
\hline CYP71A20 & 495 & 0.242 & 55 & 18.0 & $\mathrm{Y}$ \\
\hline CYP71A21 & 490 & 0.593 & 58 & 15.5 & $\mathrm{Y}$ \\
\hline CYP71A24 & 486 & 0.267 & 78 & 11.5 & $\mathrm{Y}$ \\
\hline CYP71A26 & 489 & 0.241 & 79 & 10.1 & $Y$ \\
\hline CYP71A28 & 489 & 0.495 & 83 & 20.5 & $Y$ \\
\hline CYP71B11 & 497 & 0.386 & 75 & 16.0 & $Y$ \\
\hline CYP74A1 & 518 & 0.896 & 32 & 21.9 & $\mathrm{~N}$ \\
\hline CYP74B2 & 485 & 0.814 & 29 & 31.0 & $\mathrm{~N}$ \\
\hline CYP79A2 & 531 & 0.162 & 28 & 10.7 & $Y$ \\
\hline CYP81D3 & 502 & 0.388 & 97 & 15.5 & $Y$ \\
\hline CYP84A1 & 521 & 0.384 & 64 & 20.3 & $Y$ \\
\hline СҮР97АЗ & 590 & 0.839 & 28 & 25.0 & $\mathrm{~N}$ \\
\hline CYP97C1 & 577 & 0.936 & 36 & 38.9 & $\mathrm{~N}$ \\
\hline СYР98A8 & 488 & 0.335 & 49 & 12.2 & $\mathrm{Y}$ \\
\hline \multicolumn{6}{|c|}{ Aqua colored ones are NOT predicted by chloroP as chloroplast-localized } \\
\hline
\end{tabular}

Genbank (http://www.ncbi.nih.gov/Genbank/index.html) and 1267 ESTs in the Arabidopsis thaliana Gene Index (AtGI) (http://www.tigr.org/ tigr-scripts/tgi/T_index.cgi? species= arab). Alignments of these full-length sequences with their corresponding genomic sequences shown on individual P450 locus pages at http://ArabidopsisP450.biotec.uiuc.edu/cgi-bin/p450.pl have provided supporting information for 166 of the 245 P450 loci with an additional eight P450 loci confirmed by our cloning of RT-PCR products.
With the caveat that current databases contain many P450 cDNAs derived from normal or stressed leaf tissues and small numbers of RT-PCR products cloned in directed searches for particular transcripts, enumeration of the number of full-length cDNAs for each locus indicates that substantial differences exist in the pools of different P450 subfamily and family transcripts (Table 2). Not unexpectedly, several loci with defined functions are represented by high numbers of full-length cDNAs (e.g., seven 
Table 2 Arabidopsis P450 full-length cDNAs in current databases

\begin{tabular}{|c|c|}
\hline & Number of full-length cDNAs for individual loci \\
\hline CYP51 family & $51 \mathrm{G} 1(7), 51 \mathrm{G} 2(1)$ \\
\hline CYP71 family & $\begin{array}{l}\text { 71A12 (4), 71A13 (1), 71A14 (0), 71A15 (0), 71A16 (1), 71A17P, 71A18 (0), 71A19 (2), } \\
\text { 71A20 (1), 71A21 (0), 71A22 (3), 71A23 (0), 71A24 (1), 71A25 (0), 71A26 (0), 71A27 (0), } \\
\text { 71A28 (0), 71B2 (4), 71B3 (3), 71B4 (3), 71B5 (4), 71B6 (7), 71B7 (4), 71B8 (0), 71B9 (2), } \\
\text { 71B10 (1), 71B11 (1), 71B12 (0), 71B13 (3), 71B14 (0), 71B15 (1), 71B16 (0), 71B17 (0), } \\
\text { 71B18 (1), 71B19 (4), 71B20 (5), 71B21 (0), 71B22 (1), 71B23 (1), 71B24 (0), 71B25 (0), } \\
\text { 71B26 (4), 71B27 (1), 71B28 (4), 71B29 (1), 71B30P (0), 71B31 (1), 71B32 (0), 71B33 (0), } \\
\text { 71B34 (0 + 1 bicistronic), 71B35 (0 + 1 bicistronic), 71B36 (0), 71B37 (1), 71B38 (1) }\end{array}$ \\
\hline CYP72 family & $\begin{array}{l}72 \mathrm{~A} 7(2), 72 \mathrm{~A} 8(3), 72 \mathrm{~A} 9(0), 72 \mathrm{~A} 10(0), 72 \mathrm{~A} 11(0), 72 \mathrm{~A} 12 \mathrm{P}(0), 72 \mathrm{~A} 13(4), 72 \mathrm{~A} 14(2) \\
\quad 72 \mathrm{~A} 15(2), 72 \mathrm{C} 1(0)\end{array}$ \\
\hline CYP73 family & $73 \mathrm{~A} 5(7)$ \\
\hline CYP74 family & 74A1 (9), 74B2 (6) \\
\hline CYP75 family & $75 \mathrm{~B} 1(3)$ \\
\hline CYP76 family & $76 \mathrm{C} 1$ (4), 76C2 (6), 76C3 (1), 76C4 (0), 76C5 (0), $76 \mathrm{C} 6(0), 76 \mathrm{C} 7$ (0), 76C8P (0), $76 \mathrm{G} 1$ (1) \\
\hline CYP77 family & $77 \mathrm{~A} 4$ (1), 77A5P (2), 77A6 (3), 77A7 (1), 77A8P (0), 77A9 (0), 77B1 (4) \\
\hline CYP78 family & 78A5 (3), 78A6 (0), 78A7 (2), 78A8 (0), 78A9 (5), 78A10 (0) \\
\hline CYP79 family & $\begin{array}{l}\text { 79A2 (1), 79A3P (1), 79A4P (0), 79B2 (6), 79B3 (4), 79B4P (0), 79C1 (0), 79C2 (0), } \\
\text { 79C4P (0), 79C5P (0), 79F1(3), 79F2 (3) }\end{array}$ \\
\hline CYP81 family & $\begin{array}{l}\text { 81D1 (5), 81D2 (0), 81D3 (3), 81D4 (4), 81D5 (6), 81D6 (0), 81D7 (0), 81D8 (4), 81D10 (0), } \\
\text { 81D11 (4), 81F1 (6), 81F2 (3), 81F3 (2), 81F4 (1), 81G1 (2), 81H1 (3), 81K1 (3), 81K2 (2) }\end{array}$ \\
\hline CYP82 family & $82 \mathrm{C} 2(0), 82 \mathrm{C} 3(1), 82 \mathrm{C} 4(1), 82 \mathrm{~F} 1(3), 82 \mathrm{G} 1(2)$ \\
\hline CYP83 family & $83 \mathrm{~A} 1(7), 83 \mathrm{~B} 1(4)$ \\
\hline CYP84 family & $84 \mathrm{~A} 1(1), 84 \mathrm{~A} 4(0)$ \\
\hline CYP85 family & $85 \mathrm{~A} 1(2), 85 \mathrm{~A} 2(5)$ \\
\hline CYP86 family & $\begin{array}{l}\text { 86A1 (3), 86A2 (3), 86A4 (1), 86A7 (1), 86A8 (2), 86B1 (2), 86B2 (1), 86C1 (0), 86C2 (0), } \\
\quad 86 \mathrm{C} 3(2), 86 \mathrm{C} 4 \text { (1) }\end{array}$ \\
\hline CYP87 family & $87 \mathrm{~A} 2(2), 87 \mathrm{~A} 3 \mathrm{P}(0)$ \\
\hline CYP88 family & $88 \mathrm{~A} 3(2), 88 \mathrm{~A} 4(2)$ \\
\hline CYP89 family & $89 \mathrm{~A} 2$ (5), 89A3 (0), 89A4 (0), 89A5 (5), 89A6 (0), 89A7 (1), 89A9 (3) \\
\hline CYP90 family & 90A1 (7), 90B1 (4), 90C1 (2), 90D1 (4) \\
\hline CYP93 family & 93D1 (0) \\
\hline CYP94 family & 94B1 (4), 94B2 (0), 94B3 (4), 94C1 (3), 94D1 (0), 94D2 (0), 94D3P (0) \\
\hline CYP96 family & $\begin{array}{l}96 \mathrm{~A} 1(2), 96 \mathrm{~A} 2(1), 96 \mathrm{~A} 3(0), 96 \mathrm{~A} 4(1), 96 \mathrm{~A} 5(0), 96 \mathrm{~A} 6 \mathrm{P}(0), 96 \mathrm{~A} 7(0), 96 \mathrm{~A} 8(3), 96 \mathrm{~A} 9(0), \\
96 \mathrm{~A} 10(0), 96 \mathrm{~A} 11(0), 96 \mathrm{~A} 12(3), 96 \mathrm{~A} 13(0), 96 \mathrm{~A} 14 \mathrm{P}(0), 96 \mathrm{~A} 15(2)\end{array}$ \\
\hline CYP97 family & $97 \mathrm{~A} 3(5), 97 \mathrm{~B} 3(2), 97 \mathrm{C} 1$ (2 + 1 bicistronic) \\
\hline CYP98 family & $98 \mathrm{~A} 3(2), 98 \mathrm{~A} 8(1), 98 \mathrm{~A} 9$ (1) \\
\hline CYP701 family & $701 \mathrm{A3}(3)$ \\
\hline CYP702 family & $702 \mathrm{~A} 1$ (0), 702A2 (0), 702A3 (0), 702A4P (0), 702A5 (2), 702A6 (1), 702A7P (0), 702A8 (0) \\
\hline CYP703 family & $703 \mathrm{~A} 2(2)$ \\
\hline CYP704 family & 704A1 (0), 704A2 (1), 704B1 (1) \\
\hline CYP705 family & $\begin{array}{l}\text { 705A1 (0), 705A2 (1), 705A3 (1), 705A4 (2), 705A5 (0), 705A6 (0), 705A8 (0), 705A9 (1), } \\
\text { 705A10P (0), 705A11P (0), 705A12 (0), 705A13 (0), 705A14P (0), 705A15 (3 + } 2 \text { bicistronic), } \\
\text { 705A16 (0 + 2 bicistronic), 705A17P (0), 705A18 (0), 705A19 (5), 705A20 (2), 705A21 (2), } \\
\text { 705A22 (1), 705A23 (0), 705A24 (0), 705A25 (2), 705A26P (0), 705A27 (2), 705A28 (0), } \\
\text { 705A29P (0), 705A30 (0), 705A31P (0), 705A32 (0), 705A33 (1), 705A34 (0) }\end{array}$ \\
\hline CYP706 family & 706A1 (7), 706A2 (4), 706A3 (2), 706A4 (3), 706A5 (2), 706A6 (2), 706A7 (3) \\
\hline CYP707 family & 707A1 (4), 707A2 (1), 707A3 (4), 707A4 (1) \\
\hline CYP708 family & $708 \mathrm{~A} 1(0), 708 \mathrm{~A} 2(2), 708 \mathrm{~A} 3(3), 708 \mathrm{~A} 4(0)$ \\
\hline CYP709 family & 709B1(4), 709B2 (3), 709B3 (0) \\
\hline CYP710 family & $710 \mathrm{~A} 1$ (3), 710A2 (6), 710A3 (0), 710A4 (1) \\
\hline CYP711 family & $711 \mathrm{~A} 1(2)$ \\
\hline CYP712 family & $712 \mathrm{~A} 1(1), 712 \mathrm{~A} 2(0)$ \\
\hline CYP714 family & 714A1 (3), 714A2 (2) \\
\hline CYP715 family & $715 \mathrm{~A} 1(0)$ \\
\hline CYP716 family & $716 \mathrm{~A} 1(0), 716 \mathrm{~A} 2(0)$ \\
\hline CYP718 family & $718 \mathrm{~A} 1$ (1) \\
\hline CYP720 family & $720 \mathrm{~A} 1(0)$ \\
\hline CYP721 family & $721 \mathrm{~A} 1(0)$ \\
\hline CYP722 family & $722 \mathrm{~A} 1(0)$ \\
\hline CYP724 family & $724 \mathrm{~A} 1(0)$ \\
\hline CYP734 family & $734 \mathrm{~A} 1(3)$ \\
\hline CYP735 family & 735A1 (1), 735A2 (3) \\
\hline
\end{tabular}


for CYP51G1 in sterol synthesis, eight for CYP74A1 in JA synthesis, eight for CYP83A1 in glucosinolate synthesis, seven for CYP90A1 in BL synthesis) and some with as-yet-undefined functions (e.g., seven for CYP71B6, eight for CYP81F1, five for CYP705A19). In total, 20 of 245 P450 loci are represented by five or more full-length cDNAs in databases. Presumably reflecting the abundance of their transcripts in the types of RNA samples used for construction of these cDNA libraries, 53 other loci are represented by three or four full-length cDNAs, 93 other loci are represented by one or two fulllength cDNAs and 106 other loci have no available full-length cDNAs. Transcripts for the 27 full-length pseudogenes and pseudogene fragments in the genome are discussed below. These full-length P450 cDNA counts reflect sequences in the dbEST (http://www.ncbi.nlm.nih.gov/Genbank/index.html), RIKEN (http://rarge.gsc.riken. go.jp/) and CERES (ftp://ftp.tigr.org/pub/data/ a_thaliana/ceres/) databases as of February 2006.

Analyses of these databases as well as validated and provisional REFSEQ sequences (Pruitt et al. 2002) have identified, quite surprisingly, an unusual set of five P450 transcripts in the RIKEN database spanning two adjacent loci in Arabidopsis genome. Three of these transcripts represent bicistronic transcripts spanning adjacent P450 loci that are potentially capable of coding for two complete $\mathrm{P} 450$ open reading frames (ORFs) (CYP71B34/CYP71B35), nearly complete ORFs (CYP705A15/CYP705A16) or adjacent P450 and O-methyltransferase ORFs (CYP97C1/OMT) (Thimmapuram et al. 2005). Two other unusual P450 transcripts represent monocistronic transcripts that splice two full-length P450 sequences to generate dimeric P450s not yet identified in another organism (CYP96A9/CYP96A10, CYP71A27/CYP71A28). The fact that splicing in these fused monocistronic transcripts occurs just upstream from the translation stop in the first ORF to just downstream from the signal sequence needed for ER-localization has suggested that these dimeric P450 fusion proteins may be functionally relevant for sequential modifications on hydrophobic substrates. Realizing that the identification of these unusual transcripts from adjacent loci can only be appreciated in plant species whose genomes have been completely sequenced, their existence has been verified with gene-specific P450 primers and probes and control and environmentally stressed Arabidopsis RNAs (Thimmapuram et al. 2005). As a result of this analysis, it is now apparent that the bicistronic and fused monocistronic transcripts exist side-by-side with monocistronic transcripts from each of the adjacent loci. For example, transcripts capable of coding for the dimeric CYP96A9/CYP96A10 protein exist in flowers along with abundant transcripts coding for CYP96A9 and rarer transcripts coding for CYP96A10 (Thimmapuram et al. 2005). Transcripts for the bicistronic CYP71B34/CYP71B35 and CYP97C1/OMT proteins exist in cold-and drought-stressed seedlings. Given that these unusual transcripts could not possibly have been predicted by current annotation algorithms, these transcripts have fogged existing definitions of genetic loci in the Arabidopsis genome and highlighted a number of P450 loci whose transcript profiles must take into account the fact that they are represented by both monocistronic and bicistronic transcripts.

In addition to providing support for existing gene models and some novel transcripts, our database curations have identified a few loci with alternative splicing variants. One (CYP51G1) contains an intron in its $5^{\prime}$ untranslated region while others contain cryptically spliced introns whose excision cause transcripts to code for prematurely truncated proteins (CYP71B2, CYP97C1), inefficiently spliced introns whose retention causes transcripts to code for prematurely truncated proteins (CYP71B29, CYP71B35, CYP72A13, CYP83A1, CYP707A3), introns with alternative $3^{\prime}$ splice sites whose variations cause transcripts to code for either full-length or aminoterminally truncated (missing 83 a.a.) proteins (CYP711A1) or alternative polyadenylation sites which cause intron retention and production of truncated proteins (CYP76C7). In most cases, analyses of the splice sites surrounding these aberrantly spliced introns indicate that they are nonoptimal and prone to being retained. In contrast with this, the CYP708A2 locus contains an upstream transcription start whose usage causes the transcript to code for an unusually long (76 a.a.) signal sequence rather than its shorter $(25$ 
a.a.) and more typical signal sequence. Our database curations have also identified a natural $10 \mathrm{bp}$ deletion in the coding region of the CYP74B2 gene in one commonly used ecotype (Col-0) of Arabidopsis that prevents this gene from expressing HPL activity (Duan et al. 2005). As a consequence, this particular ecotype contains an additional pseudogene (CYP74B2P) and is defective in $\mathrm{C}_{6}$-volatile production.

Even with the available cDNA clones, transcription start sites are not well defined in many of these P450 transcription units; those that lack full-length cDNAs often have no ESTs in current collections or only ESTs corresponding to the 3' ends of loci. Support for current P450 gene models will come only from additional clonings, if low level P450 transcripts can be individually targeted in RT-PCR strategies, or sequence comparisons, if their derived sequences can be aligned with similar P450 proteins to localize deletions and/or insertions relative to structurally important regions.

\section{Transcripts detected by microarray and oligoarray profiling}

Various transcript profiling strategies have been used to identify the range of P450s expressed in different tissues and those induced or repressed in response to a particular stress regime. The high degree of evolutionary duplication in this large gene family has created special challenges for defining these expression patterns and subsets of coordinately regulated genes. The one predominating complication in this analysis arises from high degree of nucleic acid identity that, if not carefully monitored against, causes related P450 sequences to cross-hybridize and leads to inaccurate expression profiling. In the time since our previous review (Schuler and Werck-Reichhart 2003) discussed the cDNA/EST-based strategies being used to evaluate $\mathrm{P} 450$ expression patterns, several oligoarray and microarray platforms have become available for either full-genome profiling or more detailed analysis of P450 and other stressresponse genes. The oligoarray platforms now include an Affymetrix ATH1 array (Redman et al. 2004) that contains 226 elements representing
226 P450 loci, a 70-mer oligoarray (http:// www.ag.arizona.edu/microarray/) that contains 243 elements representing 237 P450 loci (with elements for 15 loci potentially detecting closely related transcripts), an Agilent 60-mer oligoarray (http://www.agilent.com/chem/DNA) that contains 304 elements representing 252 P450 loci and a more focused 50-mer array that contains elements for $246 \mathrm{P} 450$ loci and 112 UGT loci (Kristensen et al. 2005). The microarray platforms now include a CATMA GST (gene-specific tag) microarray (Allemeersch et al. 2005) that contains 148 elements representing $141 \mathrm{P} 450$ loci and a P450 gene-specific microarray (built at the University of Illinois in collaboration with Genoplante) that contains 265 P450 loci alongside 365 biochemical pathway and physiological function marker loci. To facilitate interpretations of various datasets, updated annotations have been assigned to the 70-mer oligoarray and the P450 gene-specific microarray identifying probe elements capable of hybridizing to two different regions of the same P450 locus as well as probe elements potentially capable of hybridizing with other Arabidopsis loci (both P450 and non-P450 loci) sharing >95\% identity across a $70 \mathrm{nt}$. oligomer or across more than $100 \mathrm{nt}$. of a microarray element.

With these annotations in place to highlight potentially problematic loci, the process of categorizing P450 loci based on their tissue-specificity and inducibilities has begun using the more focused P450 gene-specific arrays and, to a more limited extent, the global oligoarray systems. One distinct advantage of the smaller arrays is that, because of their cost-effectiveness, it is possible to record P450 transcript levels in samples with many more datapoints per RNA sample as well as tissues and induction timepoints analyzed. With samples representing both technical and biological replicates and data analysis procedures that statistically identify all transcripts at least threefold over background at $P<0.05$, even very low P450 transcript levels can be statistically documented as being expressed (Kristensen et al. 2005; Ali et al. 2006a, 2006b). Comparisons between these small and large array systems have indicated that, often, transcript profilings done with more limited sets of 3-4 datapoints per sample in the global arrays fail to detect low 
Table 3 Tissue specificity of P450s within some of the larger P450 subfamilies

\begin{tabular}{|c|c|c|c|c|c|c|c|}
\hline ID & Locus & function & Shoot & Root & Leaf & Stem & Flower \\
\hline \multicolumn{8}{|c|}{ CYP71A subfamily } \\
\hline CYP71A12 & At2g30750 & P450 & ND & 2.11 & 1.51 & ND & 0.55 \\
\hline CYP71A13 & At2g30770 & P450 & 4.63 & 0.35 & 2.39 & ND & 0.44 \\
\hline CYP71A14 & At5g24960 & P450 & 3.56 & 2.71 & 0.40 & 0.12 & 0.59 \\
\hline CYP71A15 & At5g24950 & P450 & 5.13 & ND & 0.42 & 0.09 & ND \\
\hline CYP71A16 & At5g42590 & P450 & 0.64 & 8.61 & 0.05 & 6.75 & 0.25 \\
\hline CYP71A17P & $\mathrm{N} / \mathrm{A}$ & P450 pseudogene & 3.29 & ND & ND & 0.08 & 0.27 \\
\hline CYP71A18 & At1g11610 & P450 & 4.51 & 0.72 & ND & 0.39 & 5.54 \\
\hline CYP71A19 & At4g13290 & P450 & 0.84 & 9.22 & 0.04 & 3.54 & 0.54 \\
\hline CYP71A20 & At4g13310 & P450 & 1.48 & 6.76 & 0.24 & 1.73 & 1.71 \\
\hline CYP71A21 & At3g48320 & P450 & 3.11 & 1.55 & 1.51 & 2.11 & 2.42 \\
\hline CYP71A22 & At3g48310 & P450 & 4.88 & ND & 2.21 & 0.39 & 1.39 \\
\hline CYP71A23 & At3g48300 & P450 & 5.24 & ND & ND & 0.25 & 2.11 \\
\hline CYP71A24 & At3g48290 & P450 & 0.93 & 0.44 & 1.29 & ND & 9.44 \\
\hline CYP71A25 & At3g48280 & P450 & 4.85 & ND & 2.92 & 2.85 & 9.71 \\
\hline CYP71A26 & At3g48270 & P450 & 4.96 & 0.75 & ND & ND & 1.13 \\
\hline CYP71A27 & At4g20240 & P450 & 0.94 & 11.59 & ND & 4.82 & 0.18 \\
\hline CYP71A28 & At4g20240 & P450 & ND & 2.87 & 1.18 & ND & 0.26 \\
\hline \multicolumn{8}{|c|}{ CYP71B subfamily } \\
\hline CYP71B2 & At1g13080 & P450 & 2.56 & 2.30 & 1.08 & 3.21 & 1.08 \\
\hline CYP71B3 & At3g26220 & P450 & 4.26 & 0.33 & 2.70 & 0.81 & 0.48 \\
\hline CYP71B4 & At3g26280 & P450 & 4.16 & 0.02 & 2.74 & 0.98 & 0.24 \\
\hline CYP71B5 & At3g53280 & P450 & 3.88 & ND & 2.49 & 4.19 & 0.65 \\
\hline CYP71B6 & At2g24180 & P450 & 1.59 & 2.25 & 1.07 & 1.71 & 1.34 \\
\hline CYP71B7 & At1g13110 & P450 & 4.84 & 2.83 & 2.03 & 0.99 & 0.32 \\
\hline CYP71B8 & At5g35715 & P450 & 2.74 & ND & ND & ND & 5.41 \\
\hline CYP71B9 & At2g02580 & P450 & ND & 0.34 & ND & ND & 1.04 \\
\hline CYP71B10 & At5g57260 & P450 & 4.26 & 1.66 & ND & 0.33 & 2.78 \\
\hline CYP71B11 & At5g25120 & P450 & 1.68 & 3.60 & 2.57 & 5.31 & ND \\
\hline CYP71B12 & At5g25130 & P450 & 1.06 & 0.56 & 1.39 & 10.47 & 1.12 \\
\hline CYP71B13 & At5g25140 & P450 & 1.03 & 0.70 & 1.46 & 2.94 & 0.73 \\
\hline CYP71B14 & At5g25180 & P450 & 2.16 & 4.14 & 0.72 & 5.00 & 2.92 \\
\hline CYP71B15 & At3g26830 & camalexin synthesis & 5.62 & 5.59 & 1.96 & 0.07 & 0.42 \\
\hline CYP71B16 & At3g26150 & P450 & 8.01 & ND & 1.69 & 0.08 & 1.27 \\
\hline CYP71B17 & At3g26160 & P450 & 2.08 & 0.17 & 2.21 & 0.28 & 1.27 \\
\hline
\end{tabular}

abundance P450 transcripts. Exemplifying the sensitivity of the more focused P450 arrays, transcript profiles for shoots and roots of 7-dayold seedlings vs. flowers, stems and leaves of 1-month-old plants defined on our P450 microarrays have identified a significant fraction $(86-93 \%)$ of the P450 loci that are expressed at some level in seedlings and mature flowering plants with significant variations in the abundance of individual transcripts in different tissues and in different P450 subfamilies (Ali et al. 2006a). Examples of these differences exist in the 5-member CYP86A subfamily that contains functionally characterized fatty acid hydroxylases (Benveniste et al. 1998; Wellesen et al. 2001;
Duan and Schuler 2005; Rupasinghe et al. 2006), the 37-member CYP71B subfamily that contains CYP71B15 in camalexin synthesis (Zhou et al. 1999; Schuhegger et al. 2006) and 36 uncharacterized members and the 17-member CYP71A subfamily that contains several flower-specific transcripts. Expression patterns for these subfamilies normalized to the transcript levels in a universal control (e.g., RNA from all aerial tissues of 1-month-old plants and root tissue from 7-day-old seedlings) are shown in Table 3 with blue designating normalized ratios higher than 2.0, green designating ratios are less than 0.5 and ND (not detectable) designating loci have no signal over background in any of 8 datapoints. 
Table 3 continued

\begin{tabular}{|c|c|c|c|c|c|c|c|}
\hline ID & Locus & function & Shoot & Root & Leaf & Stem & Flower \\
\hline CYP71B18 & At3g26165 & P450 & ND & ND & 3.52 & ND & 1.00 \\
\hline CYP71B19 & At3g26170 & P450 & 3.70 & 0.01 & 2.36 & 1.10 & 1.67 \\
\hline CYP71B20 & At3g26180 & P450 & 3.01 & ND & 2.29 & 1.16 & 2.37 \\
\hline CYP71B21 & At3g26190 & P450 & 3.97 & 0.69 & ND & 0.07 & 0.46 \\
\hline CYP71B22 & At3g26200 & P450 & 5.89 & 0.06 & 1.20 & 2.64 & 7.95 \\
\hline CYP71B23 & At3g26210 & P450 & 2.88 & 2.59 & 2.84 & 1.38 & 0.30 \\
\hline CYP71B24 & At3g26230 & P450 & 2.42 & 0.02 & 3.05 & 2.01 & 0.69 \\
\hline CYP71B25 & At3g26270 & P450 & 3.29 & ND & ND & ND & 2.72 \\
\hline CYP71B26 & At3g26290 & P450 & 4.01 & 1.45 & 1.68 & 5.74 & 2.31 \\
\hline CYP71B27 & At1g13070 & P450 & 4.87 & ND & ND & ND & 5.37 \\
\hline CYP71B28 & At1g13090 & P450 & 1.40 & 0.81 & 1.44 & 2.13 & 2.03 \\
\hline CYP71B29 & At1g13100 & P450 & 3.17 & 4.21 & 1.62 & 0.29 & 0.78 \\
\hline CYP71B30P & At3g53290 & P450 pseudogene & 6.08 & ND & 3.23 & 0.05 & 0.32 \\
\hline CYP71B31 & At3g53300 & P450 & ND & 0.72 & 2.29 & 0.05 & 14.42 \\
\hline CYP71B32 & At3g53290 & P450 & 1.12 & 0.87 & 0.96 & 0.93 & 0.79 \\
\hline CYP71B33 & At3g26295 & P450 & 1.50 & ND & 1.42 & 1.09 & 1.26 \\
\hline CYP71B34 & At3g26300 & P450 & 3.13 & 1.38 & 0.93 & 1.67 & 1.51 \\
\hline CYP71B35 & At3g26310 & P450 & 3.00 & 0.33 & 1.58 & 1.79 & 2.16 \\
\hline CYP71B36 & At3g26320 & P450 & 4.44 & 2.55 & 1.86 & 1.04 & 1.03 \\
\hline CYP71B37 & At3g26330 & P450 & 1.21 & 3.44 & 0.56 & ND & 1.77 \\
\hline & \multicolumn{7}{|c|}{ indicates ratio of at least 2.0} \\
\hline & \multicolumn{7}{|c|}{ indicates ratio of at most 0.5} \\
\hline & \multicolumn{7}{|c|}{ indicates statistically insignificant data derived from from less than 4 of 8 datapoints } \\
\hline \multicolumn{8}{|c|}{$\begin{array}{l}\text { Normalized ratios are presented for transcripts compared to a universal control derived from all aerial tissues of } \\
\text { a one-month-old seedling and root tissue of seven-day-old seedlings. }\end{array}$} \\
\hline
\end{tabular}

Ratios designated in yellow are those derived from a small number of datapoints (less than four of eight datapoints) that are not statistically significant and often represent transcripts whose signal levels are close to the background levels on these P450 microarrays; all of these should be viewed as statistically nondetectable. At this level of comparison, it is evident that members within individual subfamilies are independently regulated with examples in the CYP71A subfamily including the flower-specific CYP71A24 and rootspecific CYP71A12 and CYP71A28. And, examples in the CYP71B subfamily including CYP71B15 that is overrepresented in seedling shoots and roots but not in stems and flowers, CYP71B14 and CYP71B26 that are expressed in all tissues analyzed and CYP71B9, CYP71B18, and CYP71B25 that are undetectable in all tissues. An expanded table showing the tissuespecificity of these Arabidopsis P450s exists at http://arabidopsis-P450.biotec.uiuc.edu.
Side-by-side comparisons of the average raw scores and normalized ratios for the CYP86A subfamily shown in Table 4 indicate the significant range of signal intensities detected for members of individual subfamilies. In particular, CYP86A2 is exceptionally abundant and expressed in most tissues while CYP86A1 is exceptionally abundant in root and marginally detectable in other tissues (Duan and Schuler 2005). Similar comparisons of the signal levels obtained for all P450 loci indicate that several P450 transcripts accumulate at extremely high levels in all tissues while others accumulate at high levels in more limited sets of tissues. Using an arbitrary average signal cut-off of 1000, two P450 transcripts (CYP73A5, CYP705A16) appear to be constitutively expressed at significantly higher levels than other P450 transcripts (Table 5). The high signal intensities of the CYP73A5 element are consistent with its significant transcript levels observed in previous 


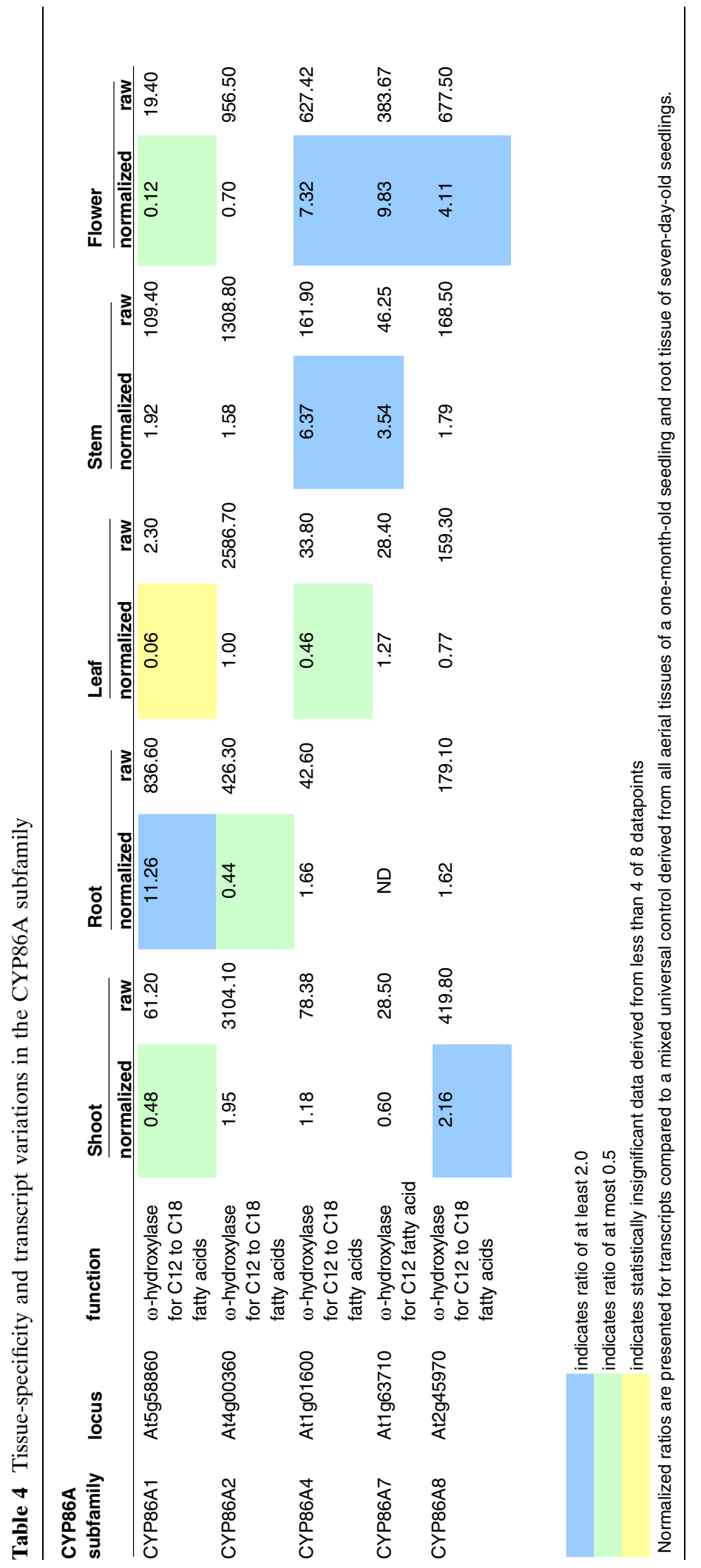


Table 5 Tissue-specificity of P450 transcripts abundant under normal growth conditions

\begin{tabular}{|c|c|c|c|c|c|c|c|c|c|}
\hline \multicolumn{2}{|l|}{ Shoot } & \multicolumn{2}{|l|}{ Root } & \multicolumn{2}{|l|}{ Stem } & \multicolumn{2}{|l|}{ Leaf } & \multicolumn{2}{|l|}{ Flower } \\
\hline CYP & $\begin{array}{l}\text { Raw } \\
\text { Scores }\end{array}$ & CYP & $\begin{array}{l}\text { Raw } \\
\text { Scores }\end{array}$ & CYP & $\begin{array}{l}\text { Raw } \\
\text { Scores }\end{array}$ & CYP & $\begin{array}{l}\text { Raw } \\
\text { Scores }\end{array}$ & CYP & $\begin{array}{l}\text { Raw } \\
\text { Scores }\end{array}$ \\
\hline CYP706A1 & 5536.40 & CYP705A16 & 5946.20 & CYP83A1 & 6140.00 & CYP705A16 & 6614.30 & CYP73A5 & 2720.33 \\
\hline$\overline{\text { CYP73A5 }}$ & 3110.30 & CYP73A5 & 4103.10 & CYP73A5 & 4865.00 & CYP74A1 & 5549.30 & CYP51G1 & 2379.40 \\
\hline CYP86A2 & 3104.10 & CYP83B1-1 & 2670.70 & CYP79F1 & 2166.80 & CYP706A1 & 3266.90 & CYP705A16 & 2217.50 \\
\hline CYP83A1 & 2675.30 & CYP79B2 & 2504.20 & CYP83B1-1 & 2037.40 & $\overline{\text { CYP81G1** }}$ & 3085.30 & CYP98A9** & 1529.75 \\
\hline CYP705A16 & 2355.20 & CYP83B1-2 & 2445.80 & CYP84A1 & 1973.50 & CYP83B1-2 & 3071.70 & CYP81G1** & 1410.58 \\
\hline CYP81G1** & 2270.00 & CYP81F4** & 2092.50 & CYP706A1 & 1973.30 & CYP83B1-1 & 2696.50 & CYP706A3 & 1350.50 \\
\hline CYP83B1-1 & 2141.40 & CYP79B3 & 2064.80 & $\overline{\text { CYP705A16 }}$ & 1959.90 & CYP86A2 & 2586.70 & CYP708A3 & 1174.33 \\
\hline CYP83B1-2 & 2076.40 & CYP708A2 & 1695.90 & CYP81G1** & 1799.60 & CYP83A1 & 2558.40 & CYP72A13 & 1151.90 \\
\hline CYP74A1 & 1942.10 & CYP51G1 & 1665.60 & CYP83B1-2 & 1611.90 & CYP72A13 & 2442.30 & & \\
\hline CYP51G1 & 1900.20 & CYP81D1-1 & 1646.60 & CYP708A3 & 1526.10 & CYP90A1 & 2318.50 & & \\
\hline CYP71B7 & 1449.30 & CYP705A5 & 1507.70 & CYP86A2 & 1308.80 & CYP71B32 & 1606.30 & & \\
\hline CYP706A2 & 1345.70 & CYP51G2-1 & 1032.00 & CYP74A1 & 1275.00 & CYP73A5 & 1517.00 & & \\
\hline CYP72A11 - 1* & 1242.90 & & & CYP51G1 & 1066.80 & CYP79B3 & 1284.30 & & \\
\hline$\overline{\overline{\text { CYP79F1 }}}$ & 1237.80 & & & & & CYP79F1 & 1127.00 & & \\
\hline CYP98A9** & 1224.70 & & & & & CYP51G2-1 & 1086.60 & & \\
\hline CYP81D1-1 & 1222.00 & & & & & CYP71B4 & 1009.80 & & \\
\hline CYP84A1 & 1158.10 & & & & & & & & \\
\hline CYP90A1 & 1101.00 & & & & & & & & \\
\hline CYP79B2 & 1022.70 & & & & & & & & \\
\hline
\end{tabular}

Probes on the P450 microarray which overlap an adjacent P450 gene for at least 50 nt are designated with asterisk $\left(^{*}\right)$, probes which overlap an adjacent non-P450 gene for at least $50 \mathrm{nt}$ are designated with double asterisk ( ${ }^{* *}$ ), probes with potential to cross-hybridize with non-adjacent P450 transcripts (>95\% $100 \mathrm{nt}$.) are underlined ( $\_$), probes with potential to cross-hybridize with non-adjacent non-P450 transcripts (>95\% $100 \mathrm{nt}$.) are double underlined $(=)$

studies (Bell-Lelong et al. 1997; Mizutani et al. 1997). The high signal intensities of the CYP705A16 element are likely due to its existence in the long bicistronic CYP705A15/ CYP706A16 transcript from this region of the genome (Thimmapuram et al. 2005). Other transcripts that are abundant in many tissues include CYP51G1 in sterol synthesis (Kushiro et al. 2001; Kim et al. 2005b) that has high signal in all except mature leaves (where its signal falls just below 1000), CYP81G1 (function undefined), CYP706A1 (function undefined) and CYP86A2 in fatty acid synthesis (Xiao et al. 2004; Duan and Schuler 2005) that have high signals in all except roots, CYP83B1 in indole glucosinolate synthesis (Bak et al. 2001; Bak and Feyereisen 2001) that has high signal in all except flowers, CYP74A1 in JA synthesis (Laudert et al. 1996) that has high signal in all except roots and flowers and CYP90A1 in BL synthesis (Szekeres et al. 1996) that has high signal in seedling shoots and mature leaves. Without detailing each and every locus, the numbers of moderately abundant P450 transcripts (signal intensities in the 200-1000 range) are 48 for seedling shoots, 30 for seedling roots and mature stems, 33 for mature leaves and 49 for flowers. Many other loci exist in the low abundance or undetectable range (with signal intensities below 200).

For evaluative purposes, some of the datasets obtained from the focused P450 microarray have been compared with those obtained using the more expensive 22,745 element ATH1 Affymetrix arrays and 27,216 element 70-mer arrays (Kristensen et al. 2005; Ali et al. 2006a). Using seedling root transcript profiles as a point of comparison, we have compared in Table 6 the root transcript profiles for all P450 genes and pseudogenes with root cell-specific transcript profiles for 6-day-old seedlings (Birnbaum et al. 2003). Because this particular Affymetrix dataset details expression levels in five root cell types (stele, endodermis, endodermis plus cortex, epidermal atrichoblast, lateral root cap) abundant in primary roots but not quiescent center or columellar root cap cells (Nawy et al. 2005), comparisons with our seedling root datasets have 
Table 6 Comparison of P450 microarray and Affymetrix ATH1 array datasets

\begin{tabular}{|c|c|c|c|c|c|}
\hline & $\begin{array}{l}\text { Raw } \\
\text { Scores }\end{array}$ & & $\begin{array}{l}\text { Raw } \\
\text { Scores }\end{array}$ & & $\begin{array}{l}\text { Raw } \\
\text { Scores }\end{array}$ \\
\hline CYP705A16 & 5946.2 & CYP710A1 & 299.4 & CYP81H1 & 121.7 \\
\hline CYP73A5 & 4103.1 & CYP706A1 & 294.9 & CYP72A7 & 121.5 \\
\hline CYP83B1-1 & 2670.7 & CYP71B2 & 286.9 & CYP705A20 & 121.4 \\
\hline CYP79B2 & 2504.2 & CYP71A19 & 277.4 & CYP718A1 & 116.9 \\
\hline CYP83B1-2 & 2445.8 & CYP84A4** & 259.7 & CYP706A7 & 114.7 \\
\hline $\mathrm{CYP} 1 \mathrm{~F} 4^{\star *}$ & 2092.5 & CYP705A19 & 246.7 & CYP705A33 & 111.9 \\
\hline CYP79B3 & 2064.8 & CYP87A2 & 234.9 & CYP711A1** & 110.3 \\
\hline CYP708A2 & 1695.9 & CYP72A14 & 233.5 & CYP81F3-A & 104.2 \\
\hline CYP51G1 & 1665.6 & CYP84A1 & 228.4 & CYP81F3-B & 100.1 \\
\hline CYP81D1-1 & 1646.6 & CYP79F2 & 228 & CYP90B1 & 96.3 \\
\hline CYP705A5 & 1507.7 & CYP71B23 & 218.5 & CYP721A1 & 95.8 \\
\hline CYP51G2-1 & 1032 & CYP86B1 & 210.6 & CYP705A27 $^{\star \star}$ & 95 \\
\hline CYP86A1 & 836.6 & CYP710A2 & 197.5 & CYP705A15 & 94.9 \\
\hline CYP71B6** $^{*}$ & 825.2 & CYP71B26 & 195.6 & CYP705A13-L & 86.7 \\
\hline CYP71B7 & 637.6 & CYP71A21 $^{* *}$ & 193.7 & CYP734A1 & 85.8 \\
\hline CYP98A9** & 619.2 & CYP89A5 & 182.2 & CYP72C1 & 84.5 \\
\hline CYP81G1** & 600.1 & CYP71A20 & 179.5 & CYP735A2 & 77.8 \\
\hline CYP71B32 & 592.7 & CYP86A8 & 179.1 & CYP85A2 & 77.3 \\
\hline CYP71A16 & 560.7 & CYP705A1 & 171.1 & CYP81D5 & 191.13 \\
\hline CYP82F1 & 536.5 & CYP72A13 & 165.1 & CYP706A2 & 148.7 \\
\hline CYP83A1 & 505.4 & CYP707A3 & 161.9 & CYP90A1 & 142.9 \\
\hline CYP704A2 $^{\star \star}$ & 468.7 & CYP90C1 & 155.63 & CYP71B13 & 131.4 \\
\hline CYP86A2 & 426.3 & CYP71A27 & 152 & CYP71B14 & 113.4 \\
\hline CYP706A3 & 408.9 & CYP705A12 & 150.7 & CYP81D4 & 95.8 \\
\hline CYP81D11** & 402.1 & CYP705A22 & 145.9 & CYP81D8 & 92.1 \\
\hline CYP705A25 & 313.3 & CYP71B34 & 135.8 & CYP71B28 & 91.3 \\
\hline CYP74A1 & 311.6 & CYP705A30 & 133.6 & CYP94B1 & 78.38 \\
\hline CYP702A5 & 309.4 & CYP72A15 & 131.3 & CYP97A3-A & 137 \\
\hline CYP705A8 & 304.3 & CYP701A3 & 127.3 & CYP81K1 & 90.25 \\
\hline CYP72A11-1 $^{*}$ & 299.6 & CYP97A3-B & 125.6 & & \\
\hline
\end{tabular}

Blue fill designates loci having raw scores higher than 75 in both arrays (P450 and ATH1), gray fill designates P450s absent in ATH1 array and white fill designates P450 loci having raw scores higher than 75 on the P450 array and scored as not expressed on the ATH1 array.

P450s scored as expressed on the ATH1 array with raw scores less than 75 on the P450 microarray include: CYP71A15, 71B22, 78A9, 81F1, 88A3, 88A4, 90D1, 94B3, 94C1, 96A7, 98A3, 702A2, 705A2, 705A9, 705A23, 707A1, 709AB2, 714A2, 715A1, 720A1.

Probes on the P450 microarray which overlap an adjacent P450 gene for at least $50 \mathrm{nt}$ are designated with asterisk $\left(^{*}\right)$, probes which overlap an adjacent non-P450 gene for at least $50 \mathrm{nt}$ are designated with double asterisk $\left({ }^{\star \star}\right)$, probes with potential to cross-hybridize with non-adjacent P450 transcripts ( $>95 \% 100 \mathrm{nt}$.) are underlined (_ $)$, probes with potential to cross-hybridize with non-adjacent non-P450 transcripts (>95\% 100 nt.) are double-underlined (_)

been done by scoring for loci having signal levels over 75 on the Affymetrix arrays for at least one type of root cell or on microarrays for intact roots. Clearly indicating the discrepancies between these array systems, 47 (of the 224 P450s represented on both types of arrays) are scored as expressed over background in roots in both array systems (designated in blue in Table 6), 31 were scored as expressed in our P450 microarrays but not in oligoarrays (designated in white) and 20 were scored as expressed in oligoarrays but below the signal cut-offs used in our microarrays (listed at the bottom of Table 6). While not directly comparing the levels of expression levels in these array systems, these comparisons highlight the large number of P450 loci (47) whose expression agrees and the larger number of P450 loci (51) whose expression differs between these two array formats. With the RT-PCR gel blot analyses in Duan and Schuler (2005) supporting detection of rootexpressed transcripts for CYP86A2, CYP72A7, CYP74A1 and many others in both microarrays and Affymetrix array formats, there are very notable discrepancies between these two datasets. Among the differences noted for these five cell types are the CYP71B7, CYP86A1 and other transcripts (Duan and Schuler 2005). The high signals detected on our microarrays for these last two examples and the confirmation of 
their Affymetrix element sets suggest that factors other than low transcript levels or differences in RNA preparation methods contribute to the failure of Affymetrix arrays to detect these abundant P450 transcripts. The high degree of sequence identity that exists between some of the most recently duplicated P450 loci may explain some of these discrepancies since close identities of this sort have the tendency to cause recently duplicated genes to be scored as "absent" on Affimetrix arrays when they are in fact expressed. Although it does not factor into the detection problems detailed above, it is important for other researchers to note that a number of P450 elements on the ATH1 oligoarray have misleading locus annotations and CYP designations potentially complicating descriptions of the biochemical processes affected by any given treatment; the correct CYP designations for these should be: 246620_at (CYP81D1), 253101_at (CYP81F1), 251988_at (CYP71B31), 252674_at (CYP71B38), 264470_at (CYP735A2), 250838_at (CYP77A9). Apart from these problematic sets of $\mathrm{P} 450$ elements, the Affimetrix array elements that accurately record root $\mathrm{P} 450$ transcript levels demonstrate the extent of cellspecific expression of many individual $\mathrm{P} 450$ transcripts and, again, serve to group sets of P450s coordinately expressed and colocalized for common metabolic processes.

Similar comparisons between P450 microarrays and Affymetrix arrays done for ABAand IAA-treatment of 7-day-old seedlings (Ali et al. 2006b) also indicate that there are significant numbers of P450 transcripts whose expressions are not accurately recorded on Affymetrix arrays. One notable discrepancy on these Affymetrix arrays (NASC array 176 for ABA induction, NASC array 175 for IAA induction; http://affymetrix.arabidopsis.info/narrays/experimentbrowse.pl) is the recorded absence of induction for the CYP707A4 locus responsible for ABA inactivation after ABA treatment. Similar comparisons between the P450 and UGT 50-mer array and the full-genome 70-mer array have provided additional evidence supporting the fact that the focused array formats allow better detection of low abundance P450 transcripts (Kristensen et al. 2005). Continued comparative analyses of this sort is needed to define the range of P450 loci accurately and inaccurately reported on full-genome Affimetrix arrays.

Comparisons of focused P450 array datasets with previous cDNA/EST microarray datasets are difficult, if not impossible, given the different gene specificities of the shorter microarray elements that are now being used and the longer cDNA/EST microarray elements that had been used in earlier studies (Xu et al. 2001; Narusaka et al. 2004). As noted in these earlier works, signals from cDNA/EST elements sharing a high degree $(>80 \%)$ of identity over the length of the longer probes represent the summed expression levels for P450 subfamilies containing several closely related members. Signals from the shorter microarray elements are locus-specific and, where potential for cross-reactivity exists, have been annotated (as shown in Tables 5 and 6 with underlines and asterisks) to highlight this possibility and emphasize the need to verify the expression profiles of these particular elements with independent methods.

Categorization of P450s by their tissue profiles defined on P450 microarrays have identified ten clusters designated according to the tissues displaying the highest normalized ratios relative to universal controls. Not including pseudogene elements, the numbers of P450s in these clusters are: (1) constitutive (27), (2) shoot (23), (3) stem/flower (30), (4) stem/shoot (7), (5) root (46), (6) flower (20), (7) stem (18), (8) root/shoot (20), (9) leaf/ stem/shoot (21), (10) flower/shoot (22) with only eight in a group of unclassified loci. Again using root expression data to demonstrate the complexities of plant biochemistry occurring in individual tissues, the root-specific cluster (Table 7) includes many P450s and biochemical pathway markers involved in production of aliphatic and indole glucosinolates (CYP79B2, CYP79B3, CYP79F2), fatty acids (CYP86A1, CYP94B1), sterols (3-hydroxy-3-methylglutaryl CoA reductase (HMG1)), carotenoids (CYP97C1), flavonoids (chalcone isomerase (CHI2)) and cytokinins (CYP735A1) as well as an unusually large number of CYP705A subfamily members (13 of 26 total). When compiled with those in cluster 1 (constitutive) and 8 (root/shoot), the range of 
Table 7 Root-specific P450 cluster from tissue profiling of 7-day-old seedlings and 1-month-old plants

\begin{tabular}{ll}
\hline CYP71A19 & CYP702A6 \\
CYP71A20 & CYP704A1 \\
CYP71A27 & CYP705A1 \\
CYP71B37 & CYP705A5 \\
CYP72A14 & CYP705A8 \\
CYP78A8 & CYP705A9 \\
CYP79B2 (indole glucosinolate syn.) & CYP705A12 \\
CYP79B3 (indole glucosinolate syn.) & CYP705A13 \\
CYP79C4P & CYP705A15 \\
CYP79F2 (aliphatic glucosinolate syn.) & CYP705A20 \\
CYP81F3 & CYP705A23 \\
CYP81F4 & CYP705A25 \\
CYP82C4 & CYP705A27 \\
CYP82F1 & CYP705A30 \\
CYP86A1 (fatty acid syn.) & CYP705A33 \\
CYP86B1 & CYP706A7 \\
CYP87A2 & CYP708A2 \\
CYP94B1 (fatty acid syn.) & CYP710A1 (sterol syn.) \\
CYP94B3 & CYP712A1 \\
CYP97A3 (carotenoid syn.) & CYP714A2 \\
CYP97C1 (carotenoid syn.) & CYP716A2 \\
CYP702A3 & CYP718A1 \\
CYP702A4P & CYP720A1 \\
CYP702A5 & CYP735A2 (cytokinin syn.) \\
\hline
\end{tabular}

$\mathrm{P} 450$ s expressed in roots can be expanded to include additional members involved in the synthesis of cytokinins (CYP735A1), glucosinolates (CYP83B1), camalexin (CYP71B15), flavonoids (chalcone synthase (CHS1, CHS2, CHI1), sterols (CYP51G1), isoprenoids and carotenoids (1-deoxy-D-xylulose 5-phosphate synthase (DXS1)), terpenes (IPP2), degradation of abscisic acid (CYP707A3) and two members of the CYP705A subfamily. More important than simply visualizing the complexities of plant biochemistries, these types of cluster analyses narrow the range of $\mathrm{P} 450$ candidates mediating functions in this tissue and limit the scope of prospective substrates for each of the functionally undefined $\mathrm{P} 450$ s expressed in roots.

\section{Transcripts detected from pseudogenes}

The 27 Arabidopsis P450 pseudogenes that have been identified because they contain a P450 signature motif embedded within an open reading frame have open reading frames of many different lengths ranging from 102 to $1509 \mathrm{bp}$ (Table 8). The curations of full-length P450 cDNAs described above have indicated that the CYP72A12P pseudogene, which sits immediately downstream of the
CYP72A11 locus, is transcribed and terminated at alternative polyadenylation sites upstream or downstream of the CYP72A12P pseudogene yielding transcripts that terminate either 150 or $400 \mathrm{nt}$ downstream from the CYP72A11 stop codon (Table 8). Sequencing of RT-PCR products derived from this transcription unit have indicated that the longer RT-PCR product corresponds to the CYP72A12P pseudogene embedded in the $3^{\prime}$ UTR of the CYP72A11 transcript. The existence of cDNAs/ESTs for others indicates that the CYP77A5P pseudogene is expressed as part of its adjacent At3g18270 transcription unit (a mandelate racemase family protein) while others are expressed as full-length transcripts containing prematurely truncated P450 ORFs (CYP51G2P; Kim et al. 2005b) or abbreviated transcripts containing partial ORFs (CYP79A3P, CYP705A17P, CYP705A29P).

P450 microarray profiling has made it apparent that transcripts spanning several of the P450 pseudogene elements accumulate to significant levels in vivo. Using an arbitrary cut-off for average signal intensity of 75, four elements (CYP51G2P, CYP72A12P, CYP77A5P, CYP96A14P) stand out as having statistically significant signal intensities greater than this cut-off (Ali et al. 2006a). Average detectable signal intensities for these are 447-1086 for CYP51G2P, 438-788 for CYP72A12P, 125-175 for CYP77A5P and 94-114 for CYP96A14P (Table 8; Ali et al. 2006a). Detection of transcripts derived from these four loci in seedling shoots as well as other tissue samples are consistent with the existence of ESTs for these loci and/or their adjacent transcription units.

P450 microarray profiling also indicates that some nearly full-length P450 pseudogenes are not expressed at any discernible level in any tissue or chemical treatment analyzed. The CYP79A3P pseudogene that is capable of generating a prematurely truncated 467 a.a. protein produces no detectable transcripts in any of the five tissues analyzed despite the existence of a cDNA for this locus. The CYP71B30P and CYP96A9P pseudogenes that lack start codons upstream of their 448 and 275 a.a. ORFs also generate no transcripts as is consistent with the absence of cDNAs/ESTs in current databases. 


\section{Complexities of responses to chemical and environmental stresses}

More complex than the expression patterns of individual P450 loci in control plant tissues are the responses of these loci to hormones, signaling molecules and environmental stresses. Taking into account the previous cautionary notes on detection of some closely related and low copy P450 transcripts on the global arrays, the expression patterns of P450 loci that are accurately monitored on Affymetrix ATH1 arrays can be assessed in the datasets compiled for different investigators available on the websites for Genevestigator (Zimmerman et al. 2004; https:// www.genevestigator.ethz.ch/at/), TAIR (Rhee et al. 2003; http://www.arabidopsis.org/) and GEO (Barrett et al. 2005; http://www.ncbi.nlm.nih. gov/projects/geo/). These profiles, with examples for the MeJ-inducible CYP74A1, ABA-inducible CYP707A1 and root-expressed, MeJ-inducible CYP81F4 shown in Fig. 1, highlight the range of regimes modulating each $\mathrm{P} 450$ and the magnitude of their different responses. Sometimes, these datasets are limited in the number of timepoints available for an inducer, the number of chemicals tested individually and the tissues analyzed after a particular treatment. As examples, datasets are available for SA treatment of mature leaves for $2 \mathrm{~h}$ and 7-day-old seedlings for $3 \mathrm{~h}$ as well as MeJ treatment of seedlings for $30 \mathrm{~min}, 1 \mathrm{~h}$ and $3 \mathrm{~h}$ but not for any longer times or for SA and MeJ applied in combination. Virtually no datasets compare treatments with multiple chemicals to those with each of the individual chemicals. And, because these datasets are compiled from many different sources, comparisons of the magnitudes of individual responses are limited between the datasets of different investigators due to variations in labeling conditions and the various manners in which the normalizations have been performed.

Analysis on the focused P450 microarrays of the responses of selected sets of chemicals such as MeJ, SA and BION (1,2,3 benzothiodiazole-7thiocarboxylic acid $S$-methyl ester) administered to 7-day-old seedlings individually or in combination and monitored for up to $30 \mathrm{~h}$ (Ali et al. 2006b) have demonstrated that P450 loci are modulated in all sorts of interacting manners. Using just these datasets, it is possible to find subsets of P450 loci induced additively, synergistically and combinatorially by two or three of these chemicals while other subsets are antagonistically affected by competing responses to these signaling molecules and fungal defense activators. These and other datasets monitoring responses to ABA, IAA, BL, phenobarbital (a mimic for environmental pollutants), cold, drought, osmotic stress have now been able to detail "expression signatures" specific for each of these Arabidopsis P450 loci with induction/ repression magnitudes that are statistically significant and intercomparable between experiments. Using several hormone-responsive $\mathrm{P} 450 \mathrm{~s}$ as examples in Table 9, it becomes clear from the similarities in these expression signatures that P450 loci potentially coding for protein activities in the same or related pathways can be identified as coordinately regulated over a range of inducers and induction regimes. For example, CYP71A19, CYP71B19, CYP71B20, CYP71B26, CYP71B28, CYP76C2, CYP86B1, CYP89A9 and CYP94B3 are induced in response to 3 to $24 \mathrm{~h}$ ABA treatments, $3 \mathrm{~h}$ IAA treatment and $3 \mathrm{~h}$ osmotic stress along with CYP707A1 that is known to mediate ABA inactivation (Table 9). With these similarities clustering these genes in common response groups, differences in their response to other treatments and variations in the timings of their inductions/repressions allow one to discriminate subgroups that are likely to be involved in the same pathway or response. Another example of the selectivity of these response patterns is CYP78A7, which is the only $\mathrm{P} 450$ transcript besides CYP72C1 and CYP734A1 induced in response to short and long term IAA and $\mathrm{BL}$ treatments. Profiling at this level against multiple treatments has significant potential for discriminating between $\mathrm{P} 450 \mathrm{~s}$ that, although similar, moderate different branches in complex synthetic pathways as is the case with CYP85A1 and CYP85A2 in BL synthesis (Shimada et al. 2001; Kim et al. 2005a; Nomura et al. 2005).

These comparisons also make it evident that the rapidity of responses to particular chemicals has significant potential for identifying P450 loci mediating the synthesis of regulatory molecules. 


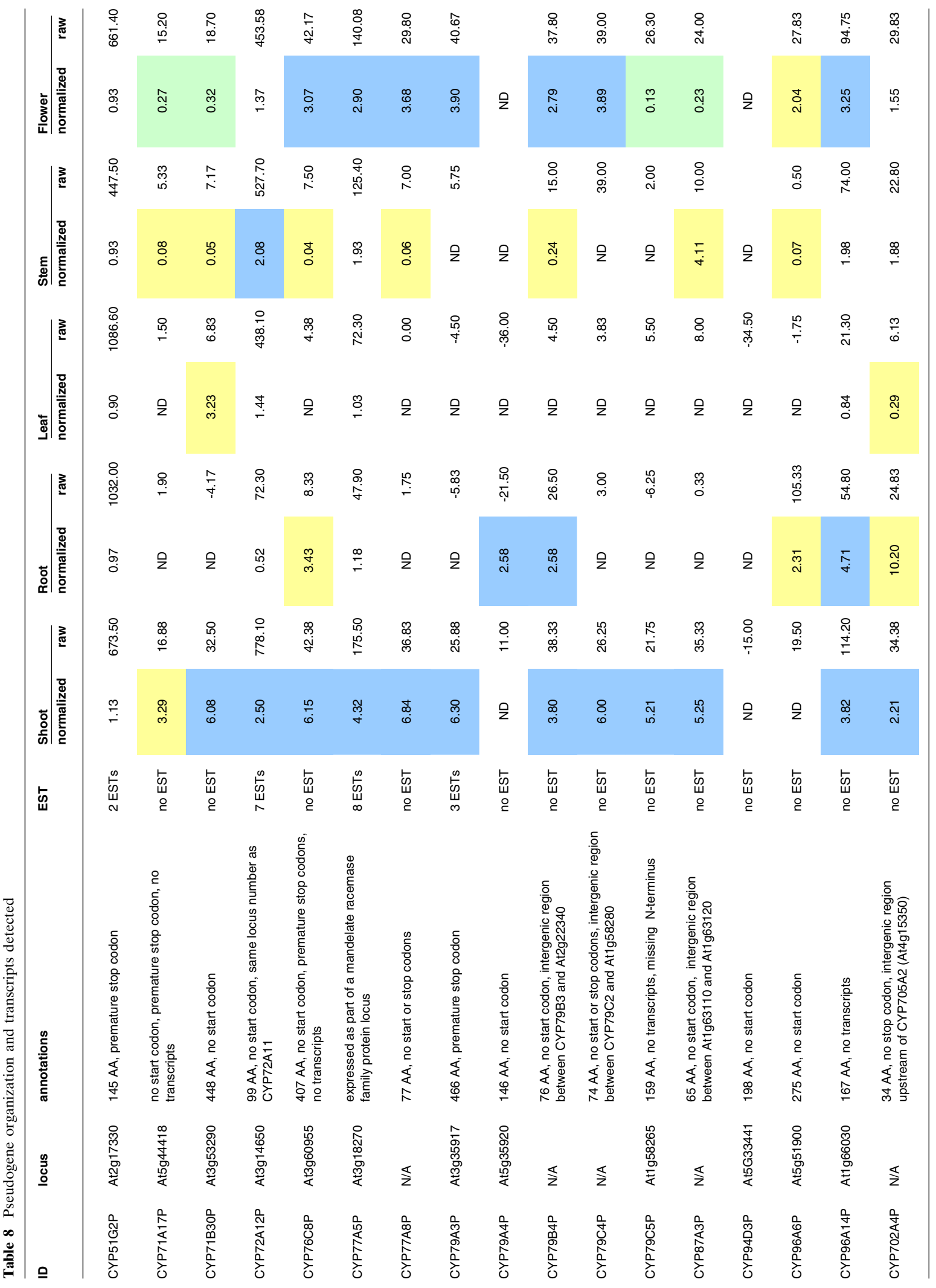




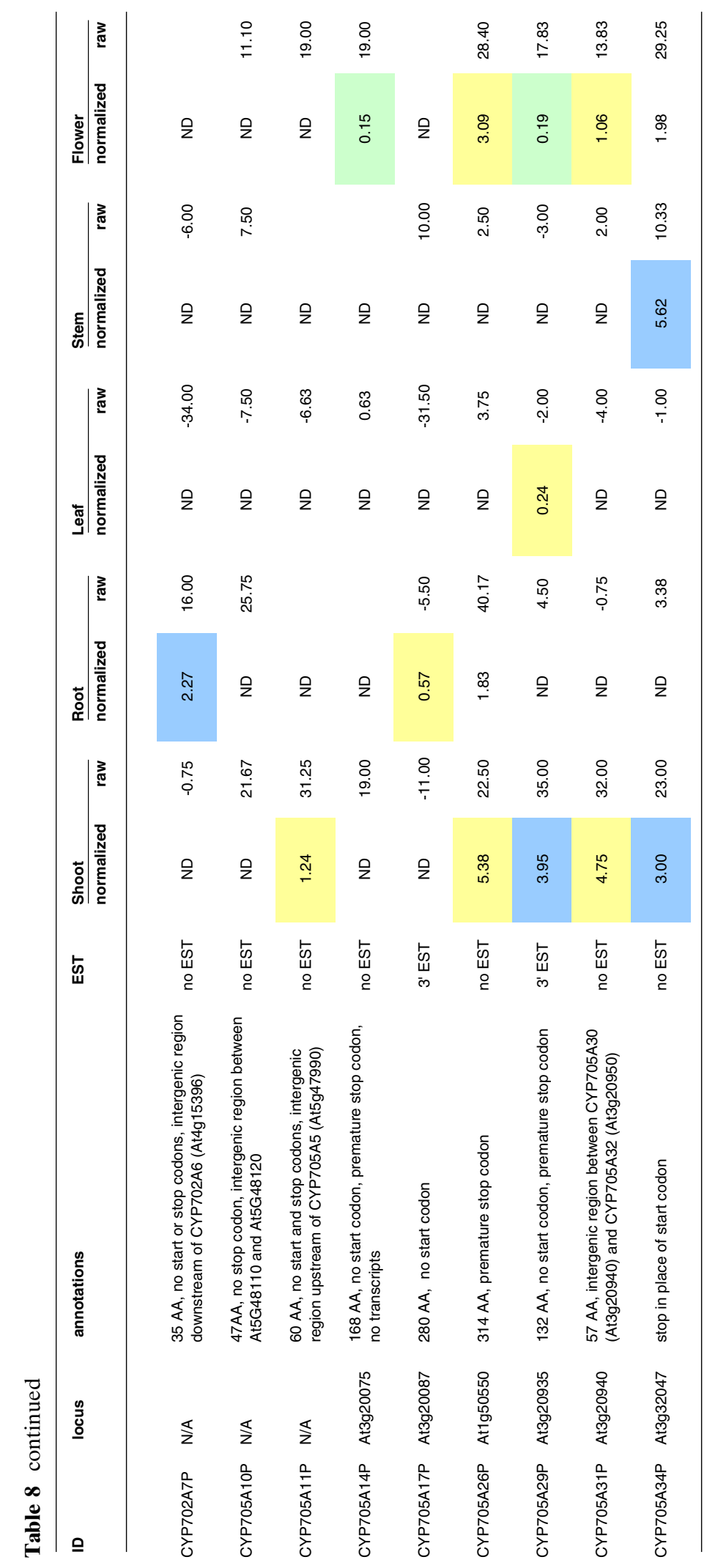




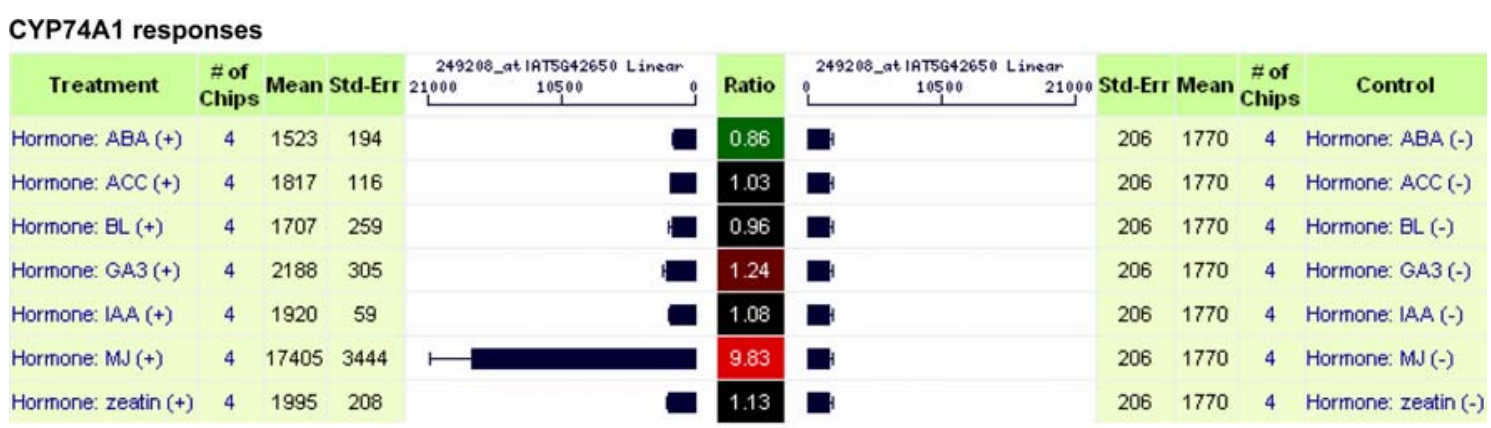

CYP81F4 responses
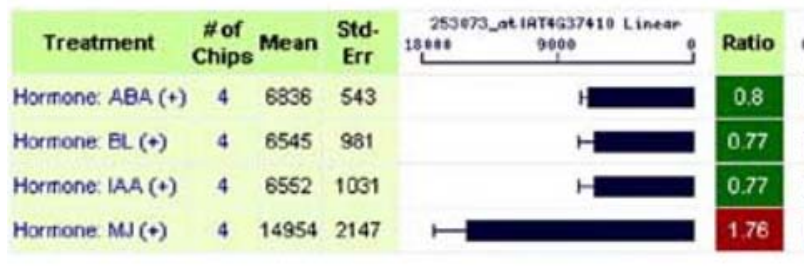

\section{CYP707A1 responses}

\begin{tabular}{|c|c|c|c|c|c|}
\hline Treatment & $\#$ of & Mean & Std- & 254562_at IRT4G19230 Linear & Patio \\
\hline & & & & 3300 & Ratio \\
\hline Hormone: $\mathrm{ABA}(+)$ & 4 & 2316 & 924 & $\vdash$ & 8.27 \\
\hline Hormone: $\mathrm{BL}(+)$ & 4 & 291 & 14 & & 1.04 \\
\hline Hormone: IAA (+) & 4 & 308 & 8 & & 1.1 \\
\hline Hormone: MJ (+) & 4 & 595 & 43 & & 2.13 \\
\hline
\end{tabular}

Fig. 1 Genevestigator data showing inducibilities for one or two P450s Induction ratios taken from the website for Genevestigator (Zimmerman et al. 2004; https://

The usefulness of evaluating expression kinetics has been especially apparent in the case of CYP94B1, where transcripts have been shown to be rapidly and transiently induced after $\mathrm{MeJ}$ treatment and whose protein has been shown to hydroxylate the plant signaling compound 9,10epoxystearic acid (Civjan et al. 2006). Other examples of the rapid induction of $\mathrm{P} 450$ s regulating hormones and signaling molecules exist in the set of four CYP707A proteins that inactivate ABA (Kushiro et al. 2004; Saito et al. 2004) and the CYP734A1 and CYP72C1 proteins that inactivate BL (Neff et al. 1999; Turk et al. 2003; Nakamura et al. 2005; Takahashi et al. 2005). Because of their important roles in maintaining hormone homeostasis, these loci respond rapidly and, in some cases, quite transiently after hormone treatment (Table 9). www.genevestigator.ethz.ch/at/) are shown for the CYP74A1 (At5g42650), CYP81F4 (At4g37410) and CYP707A1 (At4g19230) loci

\section{Determinants of substrate specificities}

The story describing the functional diversities of these many up-and down-regulated P450s evolves when one begins to compare the secondary and tertiary structures of P450s not just in Arabidopsis and other plants but in all organisms that contain them. These comparisons, which are further detailed in Rupasinghe and Schuler (2006) in this volume and Graham and Petersen (1999), indicate that most P450s have maintained secondary and tertiary structural conservations that are manifested in a core structure containing $\alpha$-helices (labeled A-K) and $\beta$-pleated sheet (labeled 1-4) surrounding a buried catalytic site (Graham and Petersen 1999; Stout 2004; Poulos and Johnson 2005). Site-directed mutagenesis studies on closely related $\mathrm{P} 450$ proteins in the 


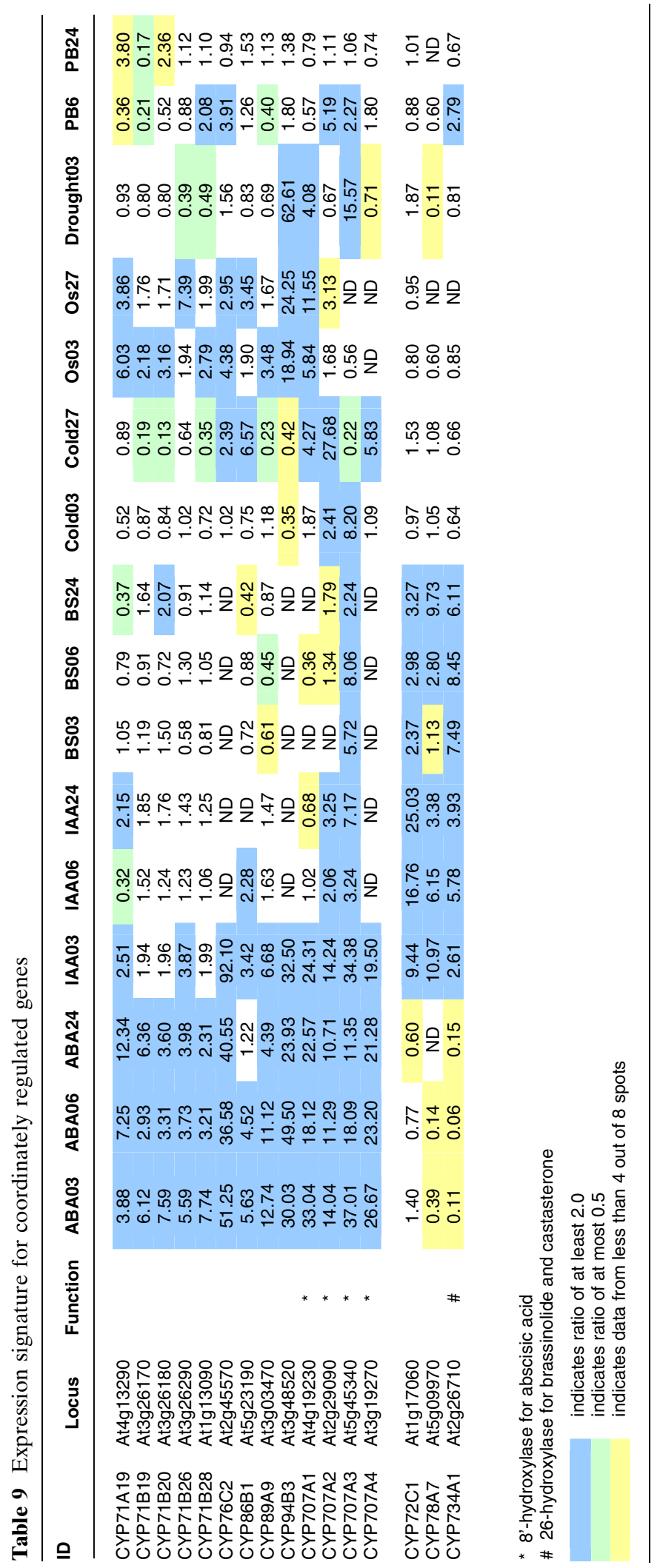


vertebrate CYP2 family have identified several substrate recognition sequences (termed SRS1-6 by Gotoh (1992)) as important for substrate metabolism as well as substrate access (Domanski and Halpert 2001). Among these, SRS1 corresponds to the loop region between the B-and C-helices positioned over the heme, SRS2 and SRS3 correspond to the F-and G-helices comprising part of the substrate access channel, SRS4 corresponds to the I-helix extending over the heme pyrrole ring B, SRS5 and SRS6 correspond to the amino-terminus of $\beta$-strand $1-4$ and the $\beta$-turn at the end of $\beta$-sheet 4 , respectively, which both protrude into the catalytic site.

Viewed from the perspective of these threedimensional structures, substrate specificity in the Arabidopsis P450s is actually defined by a small number of regions that encompass the catalytic site as fingers on your hand might hold a spacefilling model of a compound. Variations in the length of your fingers and/or their position change the position of the structure relative to the fixed plane that it sits above and any supports that surround it. Returning this analogy back to the protein sequences, increases and decreases in the lengths of the protein backbone as well as changes in the charges and sizes of a few catalytic site loops significantly impact the type of compounds that can be positioned over the heme plane and their position relative to the catalytically important I-helix that extends through the catalytic site much like a plie bar in a ballet studio.

Analyzed at this level, Arabidopsis P450 catalytic sites exhibit varying degrees of sequence diversity that do not necessarily map to their phylogenetic classifications (i.e., family, subfamily designations). There exist examples of closely related $\mathrm{P} 450$ s that differ in a few residues within most of their SRS regions and mediate similar reactions (e.g., CYP86A subfamily, Rupasinghe et al. 2006; CYP707A subfamily, Kushiro et al. 2004; Saito et al. 2004) and examples of divergent $\mathrm{P} 450$ s in completely different families that modify related aromatic substrates on the same manner (e.g., CYP73A5, CYP75B1, CYP84A1, CYP98A3; Rupasinghe et al. 2003). Examples of the most closely related P450s that differ in only one or two residues in a single SRS and mediate different reactions, such as Menta spicata CYP71D15 and M. piperita CYP71D18 (Schalk and Croteau 2000), have not yet been identified in Arabidopsis. ClustalW alignments of Arabidopsis P450 representatives from each of its subfamilies has indicated that the length variations potentially affecting substrate interactions are largely limited to the region between SRS2 and SRS3 where the loop between the F-and G-helices possibly interacts with the membrane and/or affects substrate access (Rupasinghe and Schuler 2006). Many other sequence variations that occur in the SRS1, SRS4, SRS5 and SRS6 regions (that do not vary in length) directly impact the binding properties of substrates and it is in these regions that sequence variations in closely related subfamily members allow individual proteins to metabolize the same substrate at different positions.

\section{P450 functions defined by in vitro expression strategies}

The membrane-bound nature of these proteins has created special challenges for defining their functionalities. One predominating complication arises at the protein level from the need for ER-localized P450s to pair with co-localized membrane-bound electron transfer partners such as NADPH P450 reductase and cytochrome $b_{5} / b_{5}$ reductase. Soluble P450s targeted to other subcellular locations (i.e., chloroplasts and mitochondria) utilize soluble electron transfer partners that are not restricted in their quantities or location. Details on the strategies being used for expression analysis of these P450s are covered in Duan and Schuler (2006) in this volume.

Because of these potential problems, the functions of only a small number of P450 genes present in plants have been defined by clearly establishing enzyme specificity at a biochemical level and relating it to one or more biological functions in planta. Even so, Arabidopsis ranks among the species with the most P450s functionally defined (Schuler and Werck-Reichhart 2003; http://arabidopsis-p450.biotec.uiuc.edu/functions.pdf; http: //arabidopsis.org/info/genefamily/P450_functions. 
html) with currently 41 of its full-length genes having discrete functions (Table 10) assigned using heterologous expression systems or T-DNA knockout analyses. Functions for the remaining loci are being defined with strategies that combine knowledge of their expression profiles with predictive modeling of their catalytic sites and substrate binding assays.

\section{P450 functions defined by genetic mutations}

Characterized genetic mutations in P450 loci remain limited with all currently published mutants listed in Table 11. Not unexpectedly, many of the mutant lines with obvious morphological defects have resulted from the insertion of T-DNA inserts within their coding regions that effectively silence P450 transcript production and/ or accumulation. Examples of these include the earliest CYP90A1 (cpd, cbb3) and CYP90B1 ( $d w f 4)$ knockout lines characterized for their involvement in brassinosteroid synthesis (Kauschmann et al. 1996; Szekeres et al. 1996; Choe et al. 1998; Azpiroz et al. 1998; Fujita et al. 2006), the CYP84A1 (fah1) knockout line characterized for its involvement in sinapoyl ester synthesis (Meyer et al. 1996), the CYP83B1 (sur2) knockout line characterized for its involvement in indole glucosinolate synthesis (Winkler et al. 1998) as well as the more recently identified CYP51G1 (cyp51a2) knockout lines disrupting obtusifol $14 \alpha$-demethylase and, hence, sterol production (Kim et al. 2005b).

From the perspective of the P450 molecular models mentioned previously, the mutant lines carrying EMS-derived codon changes are even more interesting. Lending support to various models, eleven changes have been identified as disrupting functions in eight P450s (Table 11). Examples of these that exist in predicted SRS regions are the R309C change in the CYP86A2 att1-1/hsr2-1 mutant (Xiao et al. 2004; M. Bevan, personal communication) that immediately precedes the highly conserved $(\mathrm{D} / \mathrm{E}) \mathrm{T}$ in the I-helix (SRS4) and the P380S change in the hsr2-2 mutant that occurs in SRS5 and is predicted to interfere with positioning of the adjacent S381V382 side chains for catalytic site contacts with fatty acid substrates (Rupasinghe et al. 2006). Other examples are the G176E change in the CYP71B15 pad3-2 mutant that occurs in the Fhelix (at the beginning of SRS2), the A291V change in the CYP83B1 atr4-2 mutant (Smolen and Bender 2002) that occurs in SRS4, the E283K change in the CYP97A3 lut5-2 mutant (Kim and DellaPenna 2006) that occurs in SRS2 and the P117L change in the CYP711A1 max1-1 mutant (Booker et al. 2005) that occurs in the B'-helix (SRS1). Others existing in recognizable structural components of these proteins outside of the SRS are the G444E change in the CYP83A1 ref2-4 mutant (Hemm et al. 2003) that occurs immediately downstream from the heme cysteine and the G444D change in the CYP98A3 ref8 mutant (Franke et al. 2002) that occurs in the L-helix that interacts with the heme. Yet others exist in regions not obviously affecting catalytic site binding and include the G58E change in the CYP90C1 rot3-2 mutant (Kim et al. 1998) that occurs in the region preceding the A'-helix where it possibly affects the structure of the adjacent $\beta$-strand 1 and the R438W change in the CYP83B1 atr4-1 mutant (Smolen and Bender 2002) that occurs in the K"helix loop which potentially interacts with P450 reductase.

The availability of large collections of insertion lines from the SALK Institute (T-DNA insertions: http://signal.salk.edu/tabout.html), SAIL (T-DNA insertions: http://www.arabidopsis.org/abrc/sail. jsp), GABI-Kat (T-DNA insertions: http://www. gabi-kat.de/), FLAG (T-DNA insertions: http:// urgv.evry.inra.fr/projects/FLAGdb++/HTML/index.shtml, Wisconsin (Ds-Lox insertions: http:// www.hort.wisc.edu/krysan/Ds-Lox/), RIKEN (Ds transposon insertions: http://rarge.gsc.riken.jp/ dsmutant/index.pl), GARNet-JIC (Ds-Spm insertions: http://garnet.arabidopsis.org.uk/transposons _for_functional_genomics.htm) and CSHL (gene trap and enhancer trap insertions: http://genetrap.cshl.org/) has made it possible to begin the characterization of knockout lines for the large number of remaining P450 loci whose transcripts are constitutively or inducibly expressed at some level in Arabidopsis. With the high level of insertional saturation in the genome and the expectation that all genes will be targeted with equal efficiency, it is notable that 23 full-length 
Table 10 P450 functions defined in Arabidopsis

\begin{tabular}{|c|c|c|c|}
\hline P450 & Activity & Pathway & References \\
\hline $51 \mathrm{G} 1$ & Obtusifoliol $14 \alpha$-demethylase & Sterols/steroids & $\begin{array}{l}\text { Kushiro et al., BBRC 285, 98-104 (2001) } \\
\text { Kim et al., Plant Physiol. 138, 2033-2047 (2005) }\end{array}$ \\
\hline 71B15 & $\begin{array}{l}\text { Conversion of s-dihydrocamalexic acid to } \\
\text { camalexin }\end{array}$ & Camalexin & $\begin{array}{l}\text { Zhou et al., Plant Cell 11, 2419-2428 (1999) } \\
\text { Schuhegger et al., Plant Physiol. 141, 1248-1254 (2006) }\end{array}$ \\
\hline $72 \mathrm{C} 1$ & Exact substrate not identified & $\begin{array}{l}\text { Degradation of } \\
\text { brassinosteroids }\end{array}$ & $\begin{array}{l}\text { Nakamura et al., J. Exptl. Bot. 413, 833-840 (2005) } \\
\text { Takahashi et al., Plant J. 42, 13-22 (2005) }\end{array}$ \\
\hline 73A5 & $\begin{array}{l}\text { Cinnamic acid 4-hydroxylase } \\
\quad(t-\mathrm{CAH})\end{array}$ & Phenylpropanoid & $\begin{array}{l}\text { Urban et al., J. Biol. Chem. 272, 19176-19186 (1997) } \\
\text { Mizutani et al., Plant Physiol. 113, 755-763 (1997) }\end{array}$ \\
\hline 74A1 & Allene oxide synthase (AOS) & Oxylipin & Laudert et al., Plant Mol. Biol. 31, 323-335 (1996) \\
\hline 74B2 & Hydroperoxide lyase (HPL) & Oxylipin & Bate et al., Plant Physiol. 117, 1393-1400 (1998) \\
\hline 75B1 & $\begin{array}{l}\text { 3'-hydroxylase for narigenin, } \\
\text { dihydrokaempferol }\left(\mathrm{F}^{\prime} \mathrm{H}\right)\end{array}$ & Phenylpropanoid & Schoenbohm et al., Biol. Chem. 381, 749-753 (2000) \\
\hline $79 \mathrm{~A} 2$ & Conversion of phenylalanine to oxime & Benzylglucosinolate & $\begin{array}{l}\text { Whittstock and Halkier, J. Biol. Chem. 275, 14659-14666 } \\
\text { (2000) }\end{array}$ \\
\hline $79 B 2$ & $\begin{array}{l}\text { Conversion of tryptophan, tryptophan analogs } \\
\text { to oxime }\end{array}$ & Indole glucosinolate & $\begin{array}{l}\text { Hull et al., Proc. Natl. Acad. Sci. 97, 2379-2384 (2000) } \\
\text { Mikkelsen et al., J. Biol. Chem. 275, 33712-33717 (2000) }\end{array}$ \\
\hline $79 B 3$ & Conversion of tryptophan to oxime & Indole glucosinolate & Hull et al., Proc. Natl. Acad. Sci. 97, 2379-2384 (2000) \\
\hline 79F1 & $\begin{array}{l}\text { Mono to hexahomomethionine in synthesis of } \\
\text { short and long chain aliphatic glucosinolates }\end{array}$ & $\begin{array}{l}\text { Aliphatic } \\
\quad \text { glucosinolate }\end{array}$ & $\begin{array}{l}\text { Hansen et al., J. Biol. Chem. 276, 11078-11085 (2001) } \\
\text { Reintanz et al., Plant Cell 13, 351-367 (2001) } \\
\text { Chen et al., Plant J. 33, 923-937 (2003) }\end{array}$ \\
\hline $79 F 2$ & $\begin{array}{l}\text { Long chain penta and hexahomomethionine in } \\
\text { synthesis of long chain aliphatic } \\
\text { glucosinolates }\end{array}$ & $\begin{array}{l}\text { Aliphatic } \\
\quad \text { glucosinolate }\end{array}$ & $\begin{array}{l}\text { Reintanz et al., Plant Cell 13, 351-367 (2001) } \\
\text { Chen et al., Plant J. 33, 923-937 (2003) }\end{array}$ \\
\hline 83A1 & $\begin{array}{l}\text { Oxidation of methionine-derived oximes } \\
\text { Oxidation of } p \text {-hydroxyphenyl-acetaldoxime, } \\
\text { indole-3-acetaldoxime }\end{array}$ & $\begin{array}{l}\text { Aliphatic } \\
\quad \text { glucosinolate }\end{array}$ & $\begin{array}{l}\text { Hemm et al., Plant Cell 15, 179-194 (2003) } \\
\text { Bak and Feyereisen, Plant Physiol. 127, 108-118 (2001) } \\
\text { Naur et al., Plant Physiol. 133, 63-72 (2003) }\end{array}$ \\
\hline 83B1 & Oxidation of indole-3-acetaldoxime & Indole glucosinolate & $\begin{array}{l}\text { Bak et al., Plant Cell 13, 101-111 (2001) } \\
\text { Bak and Feyereisen, Plant Physiol. 127, 108-118 (2001) } \\
\text { Maur et al., Plant Physiol. 133, 63-72 (2003) }\end{array}$ \\
\hline $84 \mathrm{~A} 1$ & $\begin{array}{l}\text { 5-hydroxylase for coniferaldehyde, coniferyl } \\
\text { alcohol and ferulic acid (F5H) }\end{array}$ & Phenylpropanoid & $\begin{array}{l}\text { Meyer et al., Proc. Natl. Acad. Sci. 93, 6869-6874 (1996) } \\
\text { Ruegger et al., Plant Physiol. 119, 101-110 (1999) } \\
\text { Humphreys et al., Proc. Natl. Acad. Sci. 96, 10045-10050 } \\
\quad(1999)\end{array}$ \\
\hline $85 \mathrm{~A} 1$ & $\begin{array}{l}\text { C6-oxidase for 6-deoxycastasterone, other } \\
\text { steroids }\end{array}$ & Brassinolide & $\begin{array}{l}\text { Shimada et al., Plant Physiol. 126, 770-779 (2001) } \\
\text { Shimada et al., Plant Physiol. 131, 287-297 (2003) }\end{array}$ \\
\hline $85 \mathrm{~A} 2$ & $\begin{array}{l}\text { C6-oxidase for 6-deoxycastasterone, other } \\
\text { steroids } \\
\text { Conversion of castasterone to brassinolide }\end{array}$ & Brassinolide & $\begin{array}{l}\text { Shimada et al., Plant Physiol. 131, 287-297 (2003) } \\
\text { Nomura et al., J. Biol. Chem. 280, 17873-17879 (2005) } \\
\text { Kim et al., Plant Cell 17, 2397-2412 (2005) }\end{array}$ \\
\hline $86 \mathrm{~A} 1$ & $\begin{array}{l}\omega \text {-hydroxylase for satur. and unsatur. C12 to } \\
\text { C18 fatty acids }\end{array}$ & Fatty acids & Benveniste et al., BBRC 243, 688-693 (1998) \\
\hline $86 \mathrm{~A} 2$ & $\begin{array}{l}\omega \text {-hydroxylase for satur. and unsat. } \mathrm{C} 12 \text { to } \mathrm{C} 18 \\
\text { fatty acids }\end{array}$ & Fatty acids & Duan and Schuler, Plant Physiol., 137, 1067-1081 (2005) \\
\hline $86 \mathrm{~A} 4$ & $\begin{array}{l}\omega \text {-hydroxylase for satur. and unsat. } \mathrm{C} 12 \text { to } \mathrm{C} 18 \\
\text { fatty acids }\end{array}$ & Fatty acids & Duan and Schuler, Plant Physiol., 137, 1067-1081 (2005) \\
\hline $86 \mathrm{~A} 7$ & $\omega$-hydroxylase for lauric acid & Fatty acids & Duan and Schuler, Plant Physiol., 137, 1067-1081 (2005) \\
\hline $86 \mathrm{~A} 8$ & $\begin{array}{l}\omega \text {-hydroxylase for satur. and unsatur. C12 to } \\
\text { C18 fatty acids }\end{array}$ & Fatty acids & $\begin{array}{l}\text { Wellesen et al., Proc. Natl. Acad. Sci. 98, 9694-9699 } \\
\text { (2001) }\end{array}$ \\
\hline $88 \mathrm{~A} 3$ & Multifunctional ent-kaurenoic acid oxidase & Gibberellin & $\begin{array}{l}\text { Helliwell et al., Proc. Natl. Acad. Sci. 98, 2065-2070 } \\
\text { (2001) }\end{array}$ \\
\hline $88 \mathrm{~A} 4$ & Multifunctional ent-kaurenoic acid oxidase & Gibberellin & $\begin{array}{l}\text { Helliwell et al., Proc. Natl. Acad. Sci. 98, 2065-2070 } \\
\text { (2001) }\end{array}$ \\
\hline $90 \mathrm{~A} 1$ & $23 \alpha$-hydroxylase for 6-oxo-cathasterone & Brassinolide & Szekeres et al., Cell 85,171-182 (1996) \\
\hline 90B1 & $\begin{array}{l}22 \alpha \text {-hydroxylase for } 6 \text {-oxo-campestanol, } \\
\text { campesterol and cholesterol }\end{array}$ & Brassinolide & $\begin{array}{l}\text { Choe et al., Plant Cell 10, 231-243 (1998) } \\
\text { Fujita et al., Plant J. 45, 765-774 (2006) }\end{array}$ \\
\hline $90 \mathrm{C} 1$ & Conversion of typhasterol to castasterone & Brassinolide & Kim et al., Plant J. 41, 710-721 (2005) \\
\hline 90D1 & $\begin{array}{l}\text { Exact substrate in downstream BR synthesis } \\
\text { not identified }\end{array}$ & Brassinolide & Kim et al., Plant J. 41, 710-721 (2005) \\
\hline $97 \mathrm{~A} 3$ & b -ring hydroxylase on carotenes & Carotenoid & $\begin{array}{l}\text { Kim and DellaPenna, Proc. Natl. Acad. Sci. 103, } \\
\quad 3474-3479 \text { (2006) }\end{array}$ \\
\hline $97 \mathrm{C} 1$ & $\varepsilon$-ring hydroxylase on carotenes & Carotenoid & Tian et al., PNAS 101, 402-407 (2004) \\
\hline $98 \mathrm{~A} 3$ & $\begin{array}{l}3^{\prime} \text {-hydroxylase for } p \text {-coumaryl shikimic/quinic } \\
\text { acids }\left(\mathrm{C}^{\prime} \mathrm{H}\right)\end{array}$ & Phenylpropanoid & Schoch et al., J. Biol. Chem. 276, 36566-36574 (2001) \\
\hline
\end{tabular}


Table 10 continued

\begin{tabular}{|c|c|c|c|}
\hline P450 & Activity & Pathway & References \\
\hline $701 \mathrm{~A} 3$ & Multifunctional ent-kaurene oxidase & Gibberellin & $\begin{array}{l}\text { Helliwell et al., Proc. Natl. Acad. Sci. 95, 9019-9024 } \\
\quad \text { (1998) } \\
\text { Helliwell et al., Plant Physiol. 119, 507-510 (1999) }\end{array}$ \\
\hline 707A1 & 8'-hydroxylase for $A B A$ & $\begin{array}{l}\text { Degradation of } \\
\text { abscisic acid }\end{array}$ & $\begin{array}{l}\text { Saito et al., Plant Physiol. 134, 1439-1449 (2004) } \\
\text { Kushiro et al., EMBO 23, 1647-1656 (2004) }\end{array}$ \\
\hline 707A2 & 8'-hydroxylase for $A B A$ & $\begin{array}{l}\text { Degradation of } \\
\text { abscisic acid }\end{array}$ & $\begin{array}{l}\text { Saito et al., Plant Physiol. 134, 1439-1449 (2004) } \\
\text { Kushiro et al., EMBO 23, 1647-1656 (2004) }\end{array}$ \\
\hline 707A3 & 8'-hydroxylase for ABA & $\begin{array}{l}\text { Degradation of } \\
\text { abscisic acid }\end{array}$ & $\begin{array}{l}\text { Saito et al., Plant Physiol. 134, 1439-1449 (2004) } \\
\text { Kushiro et al., EMBO 23, 1647-1656 (2004) }\end{array}$ \\
\hline 707A4 & 8'-hydroxylase for $A B A$ & $\begin{array}{l}\text { Degradation of } \\
\text { abscisic acid }\end{array}$ & $\begin{array}{l}\text { Saito et al., Plant Physiol. 134, 1439-1449 (2004) } \\
\text { Kushiro et al., EMBO 23, 1647-1656 (2004) }\end{array}$ \\
\hline $710 \mathrm{~A} 1$ & C-22 desaturase for b-sitosterol & Sterols & Morikawa et al., Plant Cell 18, 1008-1022 (2006) \\
\hline $710 \mathrm{~A} 2$ & $\begin{array}{l}\text { C-22 desaturase on 24-epi-campesterol } \\
\text { and } \beta \text {-sitosterol }\end{array}$ & Sterols & Morikawa et al., Plant Cell 18, 1008-1022 (2006) \\
\hline $734 \mathrm{~A} 1$ & $\begin{array}{l}\text { 26-hydroxylase for brassinolide and } \\
\text { castasterone }\end{array}$ & $\begin{array}{l}\text { Degradation of } \\
\text { brassinolides }\end{array}$ & $\begin{array}{l}\text { Neff et al., Proc. Natl. Acad. Sci. 96, 15316-15323 (1999) } \\
\text { Turk et al., Plant Physiol. 133, 1643-1653 (2003) }\end{array}$ \\
\hline $735 \mathrm{~A} 1$ & $\begin{array}{l}\text { trans-hydroxylase for isopentenyladenine, } \\
\text { tri/di/monophosphates }\end{array}$ & Cytokinins & Takei et al., J. Biol. Chem. 279, 41866-41872 (2004) \\
\hline $735 \mathrm{~A} 2$ & $\begin{array}{l}\text { trans-hydroxylase for isopentenyladenine, } \\
\text { tri/di/monophosphates }\end{array}$ & Cytokinins & Takei et al., J. Biol. Chem. 279, 41866-41872 (2004) \\
\hline
\end{tabular}

P450 genes still have no insertions identified within the body of their coding and intron sequences. With T-DNA knockout lines existing for several critical single-copy P450 loci (e.g., CYP73A5, CYP74A1, CYP90A1) that can be propagated as heterozygotes, the absence of insertions within these other P450 loci suggests that hemizygous knockouts containing even a single copy insertion are not viable in the processes used to construct and propagate these collections.

\section{Summary}

The view of P450-catalyzed reactions through the window of Arabidopsis biochemistry is becoming significantly more complex than originally thought when the very first P450 proteins were being purified and characterized. Rather than falling into a rabbit hole (terrier lapin, kaninchenhoehle or usagi no ana depending on your linguistic perspectives) full of confounding chemical substances and interconnecting pathways, explorations of the P450 molecular landscape are being enhanced by the large number of tools now available for monitoring $\mathrm{P} 450$ transcript levels, predicting protein structures and measuring chemical affinities as well as the genetics tools tying biochemistry to physiological functions.

The range of $\mathrm{P} 450$ genes and pseudogenes in other plant genomes is significantly less clear since, without comprehensive sequencing projects, sequences in many of these species have been identified individually as researchers have attempted to clone cDNAs coding for particular metabolic reactions. Their successes have uncovered an ever-expanding collection of $\mathrm{P} 450$ proteins and diverse metabolic reactions (Schuler and Werck-Reichhart 2003) that provide further evidence of the complex biochemistries that exist outside the window of Arabidopsis biochemistry. With the Oryza genome representing the only available annotated genome whose sequences can be compared with those in Arabidopsis (Nelson et al.2004), it is already clear that many single copy P450 gene families in Arabidopsis have been duplicated to create series of related loci whose proteins may or may not have functions related to those already characterized in Arabidopsis. With the range of genetic engineering tools more limited in Oryza and other monocots, defining functions for many of these will depend on building connections to their closest Arabidopsis relatives via molecular modeling of their catalytic sites, heterologous expression and reconstitution of their activities and, potentially, complementation analysis of Arabidopsis knockout lines that are now being characterized. Although complex, the 
Table 11 Arabidopsis P450 mutants updated

\begin{tabular}{|c|c|c|c|c|c|}
\hline P450 & $\begin{array}{l}\text { Mutant } \\
\text { locus }\end{array}$ & Allele name & $\begin{array}{l}\text { Activity/ } \\
\text { pathway }\end{array}$ & Phenotype & Reference \\
\hline \multirow[t]{2}{*}{ CYP51G1 } & cyp51A2 & $\begin{array}{l}\text { cyp51A2-2 T-DNA } \\
\text { tagged promoter } \\
\text { insertion (low } \\
\text { RNA) }\end{array}$ & $\begin{array}{l}\text { Obtusifoliol } \\
\text { 14-demethylase } \\
\text { sterols }\end{array}$ & $\begin{array}{l}\text { Defects in membrane } \\
\text { integrity, hypocotyl and } \\
\text { root elongation }\end{array}$ & $\begin{array}{l}\text { Kim et al., Plant Physiol. } \\
138,2033-2047(2005)\end{array}$ \\
\hline & & $\begin{array}{l}\text { cyp51A2-3T-DNA } \\
\text { tagged insertion } \\
\text { (null) }\end{array}$ & & $\begin{array}{l}\text { Defects in hypocotyl and } \\
\text { root elongation, seedling } \\
\text { lethal }\end{array}$ & $\begin{array}{l}\text { Kim et al., Plant Physiol. } \\
\text { 138, 2033-2047 (2005) }\end{array}$ \\
\hline CYP51G2 & cyp51A1 & $\begin{array}{l}\text { cyp51A1-1 T-DNA } \\
\text { tagged insertion } \\
\text { (null) }\end{array}$ & Undefined & $\begin{array}{l}\text { No apparent phenotypic } \\
\text { effect }\end{array}$ & $\begin{array}{l}\text { Kim et al., Plant Physiol. } \\
138,2033-2047 \text { (2005) }\end{array}$ \\
\hline CYP71B15 & pad3 & $\begin{array}{l}\text { EMS mutations } \\
\text { pad3-1 single nt } \\
\text { deletion leads } \\
\text { to frameshift } \\
\text { pad3-2 G to A } \\
\text { change leads to } \\
\text { G176 to E } \\
\text { substitution }\end{array}$ & $\begin{array}{l}\text { Conversion of } \\
\text { S-dihydrocamalexic acid to } \\
\text { camalexini }\end{array}$ & $\begin{array}{l}\text { Defect in camalexin } \\
\text { production }\end{array}$ & $\begin{array}{l}\text { Zhou et al., Plant Cell 11, } \\
\text { 2419-2428 (1999) }\end{array}$ \\
\hline \multirow[t]{2}{*}{ CYP72C1 } & chi2 & $\begin{array}{l}\text { 35S enhancer repeat } \\
\text { positioned upstream } \\
\text { from gene }\end{array}$ & $\begin{array}{l}\text { Exact reaction in } \\
\text { brassinosteroid degradation } \\
\text { not identified brassino } \\
\text { steroids }\end{array}$ & $\begin{array}{l}\text { Severely dwarfed, reduced } \\
\text { fertility, dark green } \\
\text { rounded leaves }\end{array}$ & $\begin{array}{l}\text { Nakamura et al., J. Exp. Bot. } \\
56,833-840(2005)\end{array}$ \\
\hline & sob7-D & $\begin{array}{l}\text { sob7-D activation } \\
\text { tagged suppressor } \\
\text { of the phyB- } \\
\text { 4mutation } \\
\text { sob7-1T-DNA } \\
\text { tagged } \\
\text { insertion }\end{array}$ & & $\begin{array}{l}\text { Dwarf phenotype, } \\
\text { hypocotyls hypersensitive } \\
\text { to white light wildtype } \\
\text { response to white light }\end{array}$ & $\begin{array}{l}\text { Turk et al., Plant J. 42, } \\
\text { 23-34 (2005) }\end{array}$ \\
\hline CYP74A1 & aos & T-DNA tagged insertion & $\begin{array}{l}\text { Allene oxide synthase } \\
\text { jasmonic acid }\end{array}$ & $\begin{array}{l}\text { Siliques fail to generate, } \\
\text { phenotype suppressed } \\
\text { by application of methyl } \\
\text { jasmonate }\end{array}$ & $\begin{array}{l}\text { Park et al., Plant J. 31, } \\
\text { 1-12 (2002) }\end{array}$ \\
\hline CYP75B1 & $t t 7$ & $\begin{array}{l}\text { tt7-1 EMS mutation C } \\
\text { to Tat nt } 340 \text { leads to } \\
\text { truncated protein }\end{array}$ & $\begin{array}{l}\text { Flavonoid } \\
\text { 3'-hydroxylase } \\
\text { phenylpropanoids }\end{array}$ & $\begin{array}{l}\text { Yellow or pale-brown } \\
\text { seeds due to the } \\
\text { reduction or absence of } \\
\text { pigments in the seed coat }\end{array}$ & $\begin{array}{l}\text { Schoenbohm et al., Biol. } \\
\text { Chem. 381, 749-53 } \\
\text { (2000) }\end{array}$ \\
\hline \multirow[t]{2}{*}{ CYP79F1 } & bus1 & $\begin{array}{l}\text { En-1 transposable } \\
\text { element insertions } \\
\text { bus1-1 insertion } \\
\text { in second exon } \\
\text { bus } 1-1 \text { fsingle } \\
\text { nt insertion } \\
\text { leads to } \\
\text { frameshift }\end{array}$ & $\begin{array}{l}\text { Conversion of } \\
\text { short chain methionine } \\
\text { derivatives to oximes } \\
\text { aliphatic glucosinolates }\end{array}$ & $\begin{array}{l}\text { Bushy phenotype with } \\
\text { crinkled leaves and } \\
\text { retarded } \\
\text { vascularizaton }\end{array}$ & $\begin{array}{l}\text { Reintanz et al., Plant Cell } \\
13,351-367 \text { (2001) }\end{array}$ \\
\hline & sps & Ds insertion & & $\begin{array}{l}\text { Massive proliferation of } \\
\text { shoots }\end{array}$ & $\begin{array}{l}\text { Tantilanjana et al., } \\
\text { Genes \& Develop. } \\
\text { 15, 1577-1588 (2001) }\end{array}$ \\
\hline
\end{tabular}


Table 11 continued

\begin{tabular}{|c|c|c|c|c|c|}
\hline P450 & $\begin{array}{l}\text { Mutant } \\
\text { locus }\end{array}$ & Allele name & $\begin{array}{l}\text { Activity/ } \\
\text { pathway }\end{array}$ & Phenotype & Reference \\
\hline CYP83A1 & ref2 & $\begin{array}{l}\text { EMS mutations } \\
\text { ref2-1 G to A } \\
\text { change in } \\
\text { codon } 58 \\
\text { leads to } \\
\text { truncated } \\
\text { protein } \\
\text { ref2-2 } \mathrm{G} \text { to } \mathrm{A} \\
\text { change in } 3^{\prime} \\
\text { splice site } \\
\text { ref2-3 } \mathrm{G} \text { to } \mathrm{A} \\
\text { change in } \\
\text { codon } 406 \\
\text { leads to } \\
\text { truncated } \\
\text { protein } \\
\text { ref2-4 } \mathrm{G} \text { to } \mathrm{A} \\
\text { change leads } \\
\text { to } \mathrm{G} 444 \text { to } \mathrm{E} \\
\text { substitution }\end{array}$ & $\begin{array}{l}\text { aliphatic } \\
\text { glucosinolates }\end{array}$ & $\begin{array}{l}\text { Reduced epidermal } \\
\text { fluorescence, reduced } \\
\text { sinapic acid derivatives } \\
\text { and syringyl lignin, } \\
\text { reduced aliphatic } \\
\text { glucosino- } \\
\text { lates, increased indole } \\
\text { glucosino- } \\
\text { lates }\end{array}$ & $\begin{array}{l}\text { Hemm et al., Plant Cell 15, } \\
\text { 179-194 (2003) }\end{array}$ \\
\hline \multirow[t]{3}{*}{ CYP83B1 } & sur2 & $\begin{array}{l}\text { En-1 transposable } \\
\text { element insertions } \\
\text { sur2-1 insertion } \\
\text { at } n t 441 \\
\text { relative to } \\
\text { ATG start } \\
\text { codon } \\
\text { sur2-2 } \\
\text { sequence re- } \\
\text { arrangement } \\
\text { in promoter } \\
\text { region }\end{array}$ & $\begin{array}{l}\text { Metabolism of } \\
\text { indole-3-acetyldoxime } \\
\text { indole glucosinolates }\end{array}$ & $\begin{array}{l}\text { Increased adventitious root } \\
\text { formation, increased } \\
\text { endogenous IAA level }\end{array}$ & $\begin{array}{r}\text { Barlier et al., PNAS 97, } \\
14819-14824(2000)\end{array}$ \\
\hline & atr4 & $\begin{array}{l}\text { EMS mutations } \\
\text { atr4-1C to T } \\
\text { change leads } \\
\text { to R438 to W } \\
\text { substitution } \\
\text { atr4-2 C to T } \\
\text { change leads } \\
\text { to A291 to V } \\
\text { substitution }\end{array}$ & & $\begin{array}{l}\text { Enhanced adventitious root } \\
\text { formation, lesion-mimic } \\
\text { phenotype }\end{array}$ & $\begin{array}{l}\text { Smolen and Bender, } \\
\text { Genetics 160, } \\
\text { 323-332 (2002) }\end{array}$ \\
\hline & rnt1 & $\begin{array}{l}\text { rnt1-1T-DNA } \\
\text { tagged } \\
\text { insertion }\end{array}$ & & $\begin{array}{l}\text { Small plants with hooked } \\
\text { leaves runt phenotype }\end{array}$ & $\begin{array}{c}\text { Winkler et al., Plant Physiol. } \\
\text { 118, 743-750 (1998) }\end{array}$ \\
\hline CYP84A1 & fah1 & $\begin{array}{l}\text { T-DNA tagged } \\
\text { insertion }\end{array}$ & $\begin{array}{c}\text { Ferulate 5-hydroxylase } \\
\text { phenylpropanoids }\end{array}$ & $\begin{array}{l}\text { Defective accumulation of } \\
\text { sinapic acidmetabolites }\end{array}$ & $\begin{array}{l}\text { Meyer et al., PNAS 93, } \\
\text { 6869-6874 (1996) }\end{array}$ \\
\hline CYP85A1 & сур85a1 & $\begin{array}{l}\text { T-DNA tagged } \\
\text { insertions } \\
\text { cyp85a1-1 } \\
\text { cyp85a1-2 }\end{array}$ & $\begin{array}{l}\text { C6-oxidase for } \\
\text { deoxycastasterone } \\
\text { brassinosteroids }\end{array}$ & Similar to wildtype & $\begin{array}{l}\text { Nomura et al., J. Biol. } \\
\text { Chem. 280, 17873-17839 } \\
(2005)\end{array}$ \\
\hline CYP85A2 & сур85a2 & $\begin{array}{l}\text { T-DNA tagged } \\
\text { insertions } \\
\text { cyp85a2-1 } \\
\text { cyp85a2-2 } \\
\text { cyp85a2-3 }\end{array}$ & $\begin{array}{l}\text { C6-oxidase for } \\
\text { deoxycastas- } \\
\text { terone conversion } \\
\text { of castasterone } \\
\text { to brassinolide } \\
\text { brassinosteroids }\end{array}$ & $\begin{array}{l}\text { Weak dwarf } \\
\text { during early vegetative } \\
\text { growth, reduced fertility }\end{array}$ & $\begin{array}{l}\text { Nomura et al., J. Biol. Chem. } \\
\text { 280, 17873-17839 (2005) } \\
\text { Kim et al., Plant Cell 17, } \\
\text { 2397-2412 (2005) }\end{array}$ \\
\hline CYP86A2 & att1 & $\begin{array}{l}\text { att1-1 EMS mutation } \\
\mathrm{C} \text { to } \mathrm{T} \text { change leads } \\
\text { to } \mathrm{R} 309 \text { to } \mathrm{C} \\
\text { substitution } \\
\text { att1-2 T-DNA } \\
\text { tagged insertion }\end{array}$ & $\begin{array}{c}\omega-\text { fatty acid } \\
\text { hydroxylase } \\
\text { fatty acids }\end{array}$ & $\begin{array}{l}\text { Enhanced disease severity } \\
\quad \text { to } P \text {. syringae }\end{array}$ & $\begin{array}{l}\text { Xiao et al., EMBO } \\
\text { J. 23, 292-293 (2004) }\end{array}$ \\
\hline
\end{tabular}


Table 11 continued

\begin{tabular}{|c|c|c|c|c|c|}
\hline P450 & $\begin{array}{l}\text { Mutant } \\
\text { locus }\end{array}$ & Allele name & $\begin{array}{l}\text { Activity/ } \\
\text { pathway }\end{array}$ & Phenotype & Reference \\
\hline CYP86A8 & Icr & $\begin{array}{l}\text { En-1/Spm trans- } \\
\text { posable insertions } \\
\text { Icr::En3P77 insertion } \\
\text { at nt } 72 \text { relative to } \\
\text { ATG start codon } \\
\text { Icr::En7AAA147 } \\
\text { insertion at nt } 504 \\
\text { relative to ATG start } \\
\text { codon }\end{array}$ & $\begin{array}{l}\omega \text {-fatty acid } \\
\text { hydroxylase } \\
\text { fatty acids }\end{array}$ & $\begin{array}{l}\text { Postgenital } \\
\text { organ fusion }\end{array}$ & $\begin{array}{l}\text { Wellesen et al., } \\
\text { PNAS 98, 9694-9699 } \\
\text { (2001) }\end{array}$ \\
\hline \multirow[t]{2}{*}{ CYP90A1 } & $c b b 3$ & $\begin{array}{l}\text { T-DNA tagged } \\
\text { insertion }\end{array}$ & $\begin{array}{l}23 \alpha \text {-hydroxylase for } 6 \text {-oxo- } \\
\text { cathasterone } \\
\text { brassinosteroids }\end{array}$ & Dwarf plants & $\begin{array}{l}\text { Kauschmann et al., } \\
\text { Plant J. 9, 701-713 (1996) }\end{array}$ \\
\hline & $c p d$ & T-DNA tagged insertion & & De-etiolated, dwarf plants & $\begin{array}{l}\text { Szekeres et al., Cell 85, } \\
171-182(1996)\end{array}$ \\
\hline CYP90B1 & $d w f 4$ & T-DNA tagged insertion & $\begin{array}{l}22 \alpha \text {-hydroxylase for } \\
\text { 6-oxo-campestanol } \\
\text { brassinosteroids }\end{array}$ & Dwarf plants & $\begin{array}{l}\text { Choe et al., Plant Cell 10, } \\
\text { 231-243 (1998) } \\
\text { Azpiroz et al., } \\
\text { Plant Cell 10, } \\
\text { 219-230 (1998) }\end{array}$ \\
\hline CYP90C1 & rot3 & $\begin{array}{l}\text { rot3-1 fast neutron } \\
\text { mutation deletion of } \\
>1 \mathrm{~kb} \text { in coding } \\
\text { sequence } \\
\text { rot3-2 EMS } \\
\text { mutation G } \\
\text { to A leads to } \\
\text { G58 to E sub- } \\
\text { stitution } \\
\text { rot3-3 T-DNA } \\
\text { tagged promoter } \\
\text { insertion }\end{array}$ & $\begin{array}{l}\text { Conversion of typhasterol to } \\
\text { castasterone } \\
\text { brassinosteroids }\end{array}$ & $\begin{array}{l}\text { Defect in the polar } \\
\text { elongation of leaf cells }\end{array}$ & $\begin{array}{l}\text { Kim et al., Genes \&Dev. 12, } \\
2381-2391 \text { (1998) } \\
\text { Kim et al., Plant J. 41, 710- } \\
721 \text { (2005) }\end{array}$ \\
\hline CYP90D1 & cyp90d1 & T-DNA tagged insertion & $\begin{array}{l}\text { Exact reaction in downstream } \\
\text { brassinosteroid synthesis } \\
\text { not identified } \\
\text { brassinosteroids }\end{array}$ & Similar to wildtype & $\begin{array}{l}\text { Kim et al., Plant J. 41, } \\
\text { 710-721 (2005) }\end{array}$ \\
\hline CYP97A3 & lut5 & $\begin{array}{l}\text { lut5-1 T-DNA tagged } \\
\text { insertion } \\
\text { lut5-2 EMS mutation } \\
\text { E283 to } \mathrm{K} \\
\text { substitution }\end{array}$ & $\begin{array}{l}\beta \text {-ring hydroxylation of } \\
\quad \alpha \text {-carotene carotenoids }\end{array}$ & $\begin{array}{l}\text { Increased levels } \\
\text { of } \alpha \text {-carotene, sensitive } \\
\text { to high light }\end{array}$ & $\begin{array}{c}\text { Kim and DellaPenna, PNAS } \\
103,3474-3479(2006)\end{array}$ \\
\hline CYP97C1 & lut1 & $\begin{array}{l}\text { lut1-1 } \\
\mathrm{G} \text { to A change in } 5^{\prime} \\
\text { splice site } \\
\text { lut1-2 } \\
\text { promoter } \\
\text { rearrangement } \\
\text { lut1-3 } \\
\text { T-DNA } \\
\text { tagged insertion }\end{array}$ & $\begin{array}{l}\text { Carotene } \varepsilon \text {-ring hydroxylase } \\
\text { carotenoids }\end{array}$ & Deficient in carotenoids & $\begin{array}{l}\text { Tian et al., PNAS 101, } \\
402-407(2004)\end{array}$ \\
\hline \multirow[t]{2}{*}{ CYP98A3 } & ref8 & $\begin{array}{l}\text { ref8 EMS mutation G to } \\
\text { A leads to G444 to D } \\
\text { substitution }\end{array}$ & $\begin{array}{l}\text { 3-hydroxylase for } \\
\text { p-coumaroyl } \\
\text { shikimic/ } \\
\text { quinic acids phenyl- } \\
\text { propanoids }\end{array}$ & $\begin{array}{l}\text { Reduced epidermal } \\
\text { fluorescence, dwarf } \\
\text { plants, female sterile }\end{array}$ & $\begin{array}{l}\text { Franke et al., Plant J. 30, } \\
\quad 33-45(2002)\end{array}$ \\
\hline & сур98АЗ & T-DNA tagged insertion & & $\begin{array}{l}\text { Reduced lignin, low sinopyl } \\
\text { esters, accumulate } \\
\text { flavonoid glycosides, low } \\
\text { coumarins }\end{array}$ & $\begin{array}{l}\text { Abdulrezzak et al., Plant } \\
\text { Physiol. 140, 30-48 } \\
\text { (2006) } \\
\text { Kai et al., Phyto } \\
\text { chem. 67, 379-386 (2006) }\end{array}$ \\
\hline
\end{tabular}


Table 11 continued

\begin{tabular}{|c|c|c|c|c|c|}
\hline $\mathrm{P} 450$ & Mutant locus & Allele name & $\begin{array}{l}\text { Activity/ } \\
\text { pathway }\end{array}$ & Phenotype & Reference \\
\hline CYP701A3 & ga3 & $\begin{array}{l}\text { EMS mutations } \\
\text { ga3-1 C to T } \\
\text { change at } n t \\
1609 \text { leads } \\
\text { to truncated } \\
\text { protein } \\
\text { ga3-2G to A } \\
\text { change at nt } \\
1898 \text { leads to } \\
\text { truncated } \\
\text { protein }\end{array}$ & $\begin{array}{l}\text { ent-kaurenoic acid } \\
\text { oxidase } \\
\text { gibberellins }\end{array}$ & $\begin{array}{l}\text { Failure to } \\
\text { germinate, } \\
\text { GA-responsive } \\
\text { dwarf plants }\end{array}$ & $\begin{array}{l}\text { Helliwell et al., } \\
\text { PNAS 95, 9019- } \\
9024(1998)\end{array}$ \\
\hline CYP707A1 & сур707a1 & $\begin{array}{l}\text { T-DNA tagged } \\
\text { insertions } \\
\text { cyp707a1-1 } \\
\text { cyp707a1-2 }\end{array}$ & $\begin{array}{l}\text { ABA 8'- } \\
\text { hydroxylase } \\
\text { ABA } \\
\text { inactivation }\end{array}$ & $\begin{array}{l}\text { Increased levels of } \\
\text { ABA hyper- } \\
\text { dormancy }\end{array}$ & $\begin{array}{l}\text { Okamoto et al., } \\
\text { Plant Physiol. } \\
141,97-107 \\
(2006)\end{array}$ \\
\hline CYP707A2 & сур707a2 & $\begin{array}{l}\text { T-DNA tagged } \\
\text { insertions } \\
\text { cyp707a2-1 } \\
\text { cyp707a2-2 }\end{array}$ & $\begin{array}{l}\text { ABA 8'- } \\
\text { hydroxylase } \\
\text { ABA } \\
\text { inactivation }\end{array}$ & $\begin{array}{l}\text { Increased levels of } \\
\text { ABA hyper- } \\
\text { dormancy }\end{array}$ & $\begin{array}{l}\text { Kushiro et al., } \\
\text { EMBO J. 23, } \\
1647-1656, \\
2004\end{array}$ \\
\hline CYP707A3 & сур707a3 & $\begin{array}{l}\text { T-DNA tagged } \\
\text { insertions } \\
\text { cyp707a3-1 } \\
\text { cyp707a3-2 }\end{array}$ & $\begin{array}{l}\text { ABA 8'- } \\
\text { hydroxylase } \\
\text { ABA } \\
\text { inactivation }\end{array}$ & $\begin{array}{l}\text { Increased levels of } \\
\text { ABA hyper- } \\
\text { dormancy }\end{array}$ & $\begin{array}{l}\text { Kushiro et al., } \\
\text { EMBO J. 23, } \\
\text { 1647-1656, } \\
2004\end{array}$ \\
\hline CYP710A2 & сур710a2 & $\begin{array}{l}\text { T-DNA tagged } \\
\text { insertion }\end{array}$ & $\begin{array}{l}\text { Sterol C-22 } \\
\text { desaturase } \\
\text { sterols }\end{array}$ & $\begin{array}{l}\text { No apparent } \\
\text { phenotypic } \\
\text { effects, low } \\
\text { brassicasterol/ } \\
\text { crinosterol levels }\end{array}$ & $\begin{array}{l}\text { Morikawa et al., } \\
\text { Plant Cell 45, } \\
\text { 765-774 (2006) }\end{array}$ \\
\hline CYP711A1 & $\max 1$ & $\begin{array}{l}\text { max1-1 EMS } \\
\text { mutation } C \text { to } T \\
\text { leads to } P 117 \text { to } \\
\mathrm{L} \text { substitution } \\
\text { max1-2 } \\
\text { T-DNA tagged } \\
\text { insertion }\end{array}$ & $\begin{array}{l}\text { Similar to } \\
\text { mammalian } \\
\text { thromboxane A2 } \\
\text { synthase }\end{array}$ & $\begin{array}{l}\text { Increased shoot } \\
\text { branching, } \\
\text { reduced stature }\end{array}$ & $\begin{array}{l}\text { Booker et al., } \\
\text { Develop. Cell 8, } \\
443-449 \text { (2005) }\end{array}$ \\
\hline CYP734A1 & bas1 & $\begin{array}{l}\text { bas } 1-D \text { activation } \\
\text { tagged insertion } \\
\text { in the } \\
\text { phyB-4 mutant } \\
\text { background } \\
\text { bas1-2 } \\
\text { T-DNA } \\
\text { tagged } \\
\text { insertion }\end{array}$ & $\begin{array}{l}\text { 26-hydroxylase for } \\
\text { brassinolide and } \\
\text { castasterone } \\
\text { brassino- } \\
\text { steroid } \\
\text { inactivation }\end{array}$ & $\begin{array}{l}\text { Suppressed long } \\
\text { hypocotyl } \\
\text { phenotype } \\
\text { caused by } \\
\text { mutations in } \\
\text { PHYB-4 gene, } \\
\text { hypersensitive } \\
\text { to white light, } \\
\text { wildtype } \\
\text { response to } \\
\text { white light }\end{array}$ & $\begin{array}{l}\text { Neff et al., PNAS } \\
96,15316- \\
15323 \text { (1999) } \\
\text { Turk et al., Plant } \\
\text { Physiol. 133, } \\
\text { 1643-1653 } \\
(2003) \\
\text { Turk et al., Plant J. } \\
\text { 42, 23-34 (2005) }\end{array}$ \\
\hline
\end{tabular}

view through the looking glass is clearing to reveal a set of monooxygenases integrally tied to diversification in plant biochemical pathways and defense responses.

Acknowledgments The authors gratefully thank Kara Sandfort and Anuradha Murphy for completing cDNA compilations, Sanjeewa Rupasinghe for assignments of mutations in molecular models, Dr. Jyothi Thimmpauram for bioinformatics developments and Dr. Daniele WerckReichhart for collaborating on microarray construction.
Research on Arabidopsis P450s has been supported by National Science Foundation 2010 grant MCB 0115068.

\section{References}

Ali S, Thimmapuram J, Wang H, Hudson ME, Liu L, Band M, Werck-Reichhart D, Schuler MA (2006a) Regulation of Arabidopsis thaliana P450 genes by methyl jasmonate, salicylic acid and BION: agonistic, antagonistic and combinatorial interactions. Submitted 
Ali S, Duan H, Ferhatoglu Y, Thimmapuram J, Hehn A, Goepfer S, Asnaghi C, Hudson ME, Band M, WerckReichhart D, Schuler MA (2006b) Tissue-profiling of cytochrome P450 monooxygenase transcripts expressed in Arabidopsis thaliana. Submitted

Allemeersch J, Durinck S, Vanderhaeghen R, Alard P, Maes R, Seeuws K, Bogaert T, Coddens K, Deschouwer K, Van Hummelen P, Vuylsteke M, Moreau Y, Kwekkeboom J, Wijfjes AH, May S, Beynon J, Hilson P, Kuiper MT (2005) Benchmarking the CATMA microarray. A novel tool for Arabidopsis transcriptome analysis. Plant Physiol 137:588-601

Altschul SF, Gish W, Miller W, Meyers EW, Lipman DJ (1990) Basic local alignment search tool. J Mol Biol 215:403-410

Azpiroz R, Wu Y, LoCascio JC, Feldmann KA (1998) An Arabidopsis brassinosteroid-dependent mutant is blocked in cell elongation. Plant Cell 10:219-230

Bak S, Feyereisen R (2001) The involvement of two P450 enzymes, CYP83B1 and CYP83A1, in auxin homeostasis and glucosinolate biosynthesis. Plant Physiol 127:108-118

Bak S, Tax FE, Feldmann KA, Galbraith DW, Feyereisen R (2001) CYP83B1, a cytochrome P450 at the metabolic branch point in auxin and indole glucosinolate biosynthesis in Arabidopsis. Plant Cell 13:101-111

Barrett T, Suzek TO, Troup DB, Wilhite SE, Ngau WC, Ledoux P, Rudney D, Lash AE, Fujibuchi W, Edgar R (2005) NCBI GEO: mining millions of expression profiles - database and tools. Nucleic Acids Res 33:D562-566

Bate NJ, Sivasankar S, Moxon C, Riley JMC, Thompson JE, Rothstein SJ (1998) Molecular characterization of an Arabidopsis gene encoding hydroperoxide lyase, a cytochrome P-450 that is wound inducible. Plant Physiol 117:1393-1400

Bell-Lelong DA, Cusumano JC, Meyer K, Chapple C (1997) Cinnamate-4-hydroxylase expression in Arabidopsis: regulation in response to development and environment. Plant Physiol 113:729-738

Benveniste I, Salaün J-P, Durst F (1977) Wound-induced cinnamic acid hydroxylase in Jerusalem artichoke tuber. Phytochem 16:69-73

Benveniste I, Salaün J-P, Durst F (1978) Phytochromemediated regulation of a monooxygenase hydroxylating cinnamic acid in etiolated pea seedlings. Phytochem 17:359-363

Benveniste I, Tijet N, Adas F, Philipps G, Salaün J-P, Durst F (1998) CYP86A1 from Arabidopsis thaliana encodes a cytochrome P450-dependent fatty acid omega-hydroxylase. Biochem Biophys Res Commun 243:688-693

Birnbaum K, Shasha DE, Wang JY, Jung JW, Lambert GM, Galbraith DW, Benfey PN (2003) A gene expression map of the Arabidopsis root. Science 302:19561960

Booker J, Sieberer T, Wright W, Williamson L, Willett B, Stirnberg P, Turnbull C, Srinivasan M, Goddard P, Leyser O (2005) MAX1 encodes a cytochrome P450 family member that acts downstream of MAX3/4 to produce a carotenoid-derived branch-inhibiting hormone. Dev Cell 8:443-449

Chen SX, Glawischnig E, Jørgensen K, Naur P, Jørgensen B, Olsen CE, Hansen CH, Rasmussen H, Pickett JA, Halkier BA (2003) Cytochrome P450 CYP79F1 and CYP79F2 genes catalyze the first step in the biosynthesis of short-chain and long-chain aliphatic glucosinolates in Arabidopsis. Plant J 33:923-937

Choe S, Dilkes BP, Fujioka S, Takatsuto S, Sakurai A, Feldmann KA (1998) The DWF4 gene of Arabidopsis encodes a cytochrome P450 that mediates multiple $22 \alpha$-hydroxylation steps in brassinosteroid biosynthesis. Plant Cell 10:231-243

Civjan N, Rupasinghe S, Ali S, Sligar SG, Schuler MA (2006) Arabidopsis CYP94B1 and CYP94C1: fatty acid hydroxylases induced by stress signaling molecules. Submitted

Domanski TL, Halpert JR (2001) Analysis of mammalian cytochrome P450 structure and function by sitedirected mutagenesis. Curr Drug Metab 2:117-137

Duan H, Huang M-Y, Palacio K, Schuler MA (2005) Variations in CYP74B2 (hyperoxide lyase) gene expression differentially affect hexenal signaling in the Columbia and Landsberg erecta ecotypes of Arabidopsis. Plant Physiol 139:1529-1544

Duan H, Schuler MA (2005) Differential expression and evolution of the Arabidopsis CYP86A subfamily. Plant Physiol 137:1067-1081

Duan H, Schuler MA (2006) Heterologous expression and strategies for encapsulation of membrane-localized plant P450s. Phytochem Reviews (in press)

Emanuelsson O, Nielsen H, vonHeijne G (1999) ChloroP, a neural network-based method for predicting chloroplast transit peptides and their cleavage sites. Protein Sci 8:978-9849

Emanuelsson O, Nielsen H, Brunak S, vonHeijne G (2000) Predicting subcellular localization of proteins based on their N-terminal amino acid sequence. J Mol Biol 300:1005-1016

Franke R, Humphreys JM, Hemm MR, Denault JW, Ruegger MO, Cusumano JC, Chapple C (2002) The Arabidopsis REF8 gene encodes the 3-hydroxylase of phenylpropanoid metabolism. Plant J 30:33-45

Froehlich JE, Itoh A, Howe GA (2001) Tomato allene oxide synthase and fatty acid hydroperoxide lyase, two cytochrome P450s involved in oxylipin metabolism, are targeted to different membranes of chloroplast envelope. Plant Physiol 125:306-317

Fujita S, Ohnishi T, Watanabe B, Yokota T, Takatsuto S, Fujioka S, Yoshida S, Sakata K, Mizutani M (2006) Arabidopsis CYP90B1 catalyses the early C-22 hydroxylation of $\mathrm{C}_{27}, \mathrm{C}_{28}$ and $\mathrm{C}_{29}$ sterols. Plant $\mathrm{J}$ 45:765-774

Gabriac B, Werck-Reichhart D, Teutsch H, Durst F (1991) Purification and immunocharacterization of a plant cytochrome P450: the cinnamic acid 4-hydroxylase. Arch Biochem Biophys 288:302-309

Graham SE, Petersen JA (1999) How similar are P450s and what can their differences teach us? Arch Biochem Biophys 369:24-29 
Gotoh O (1992) Substrate recognition sites in cytochrome P450 family 2 (CYP2) proteins inferred from comparative analyses of amino acid and coding nucleotide sequences. J Biol Chem 267:83-90

Hansen CH, Wittstock U, Olsen CE, Hick AJ, Pickett JA, Halkier BA (2001) Cytochrome P450 CYP79F1 from Arabidopsis catalyzes the conversion of dihomomethionine and trihomomethionine to the corresponding aldoximes in the biosynthesis of aliphatic glucosinolates. J Biol Chem 276:11078-11085

Helliwell CA, Sheldon CC, Olive MR, Walker AR, Zeevaart, JA, Peacock WJ, Dennis ES (1998) Cloning of the Arabidopsis ent-kaurene oxidase gene GA3. Proc Natl Acad Sci USA 95:9019-9024

Helliwell CA, Poole A, Peacock WA, Dennis ES (1999) Arabidopsis ent-kaurene oxidase catalyzes three steps of gibberellin biosynthesis. Plant Physiol 119:507-510

Helliwell CA, Sullivan JA, Mould RM, Gray JC, Peacock WJ, Dennis ES (2001) A plastid envelope location of Arabidopsis ent-kaurene oxidase links the plastid and endoplasmic reticulum steps of the gibberellin biosynthesis pathway. Plant J 28:201-208

Hemm MR, Ruegger MO, Chapple C (2003) The Arabidopsis ref2 mutant is defective in the gene encoding CYP83A1 and shows both phenylpropanoid and glucosinolate phenotypes. Plant Cell 15:179-194

Hull AK, Vij R, Celenza JL (2000) Arabidopsis cytochrome P450s that catalyze the first step of tryptophan-dependent indole-3-acetic acid biosynthesis. Proc Natl Acad Sci USA 97:2379-2384

Humphreys JM, Hemm MR, Chapple C (1999) New routes for lignin biosynthesis defined by biochemical characterization of recombinant ferulate 5-hydroxylase, a multifunctional cytochrome P450-dependent monooxygenase. Proc Natl Acad Sci USA 96:10045-10050

Kauschmann A, Jessop A, Koncz C, Szekeres M, Willmitzer L, Altmann T (1996) Genetic evidence for an essential role of brassinosteroids in plant development. Plant J 9:701-713

Kim GT, Tsukaya H, Uchimiya H (1998) The ROTUNDIFOLIA3 gene of Arabidopsis thaliana encodes a new member of the cytochrome P-450 family that is required for the regulated polar elongation of leaf cells. Genes Devel 12:2381-2391

Kim GT, Fujioka S, Kozuka T, Tax FE, Takatsuto S, Yoshida S, Tsukaya H (2005a) CYP90C1 and CYP90D1 are involved in different steps in the brassinosteroid biosynthesis pathway in Arabidopsis thaliana. Plant J 41:710-721

Kim HB, Schaller H, Goh CH, Kwon M, Choe S, An CS, Durst F, Feldmann KA, Feyereisen R (2005b) Arabidopsis cyp51 mutant shows postembryonic seedling lethality associated with lack of membrane integrity. Plant Physiol 138:2033-2047

Kim J, DellaPenna D (2006) Defining the primary route for lutein synthesis in plants: the role of Arabidopsis carotenoid beta-ring hydroxylase CYP97A3. Proc Natl Acad Sci USA 103:3474-3479

Kim T-W, Hwang J-Y, Kim Y-S, Joo S-H, Chang SC, Lee JS, Takatsuto S, Kim SK (2005a) Arabidopsis CYP85A2, a cytochrome P450, mediates the Baeyer-
Villiger oxidation of castasterone to brassinolide in brassinosteroid biosynthesis. Plant Cell 17:2397-2412

Kristensen C, Morant M, Olsen CE, Ekstrom CT, Galbraith DW, Moller BL, Bak S (2005) Metabolic engineering of dhurrin in transgenic Arabidopsis plants with marginal inadvertent effects on the metabolome and transcriptome. Proc Natl Acad Sci USA 102:1779-1784

Kushiro M, Nakano T, Sato K, Yamagishi K, Asami T, Nakano A, Takatsuto S, Fujioka S, Ebizuka Y, Yoshida S (2001) Obtusifoliol 14alpha-demethylase (CYP51) antisense Arabidopsis shows slow growth and long life. Biochem Biophys Res Commun 285:98104

Kushiro T, Okamoto M, Nakabayashi K, Yamagishi K, Kitamura S, Asami T, Hirai N, Koshiba T, Kamiya Y, Nambara E (2004) The Arabidopsis cytochrome P450 CYP707A encodes ABA 8'-hydroxylases: key enzymes in ABA catabolism. EMBO J 23:1647-1656

Laudert D, Pfannschmidt U, Lottspeich F, HolländerCzytko H, Weiler EW (1996) Cloning, molecular and functional characterization of Arabidopsis thaliana allene oxide synthase (CYP74), the first enzyme of the octadecanoid pathway to jasmonates. Plant Mol Biol 31:323-335

Meyer K, Cusumano JC, Somerville C, Chapple CCS (1996) Ferulate-5-hydroxylase fromArabidopsis thaliana defines a new family of cytochrome P450-dependent monooxygenases. Proc Natl Acad Sci USA 93:6869-6874

Mikkelsen MD, Hansen CH, Wittstock U, Halkier BA (2000) Cytochrome CYP79B2 from Arabidopsis catalyzes the conversion of tryptophan to indole-3-acetaldoxime, a precursor of indole glucosinolates and indole-3-acetic acid. J Biol Chem 275:33712-33717

Mizutani M, Ohta D, Sato R (1997) Isolation of a cDNA and a genomic clone encoding cinnamate 4-hydroxylase from Arabidopsis and its expression manner in planta. Plant Physiol 113:755-763

Morikawa T, Mizutani M, Aoki N, Watanabe B, Saga H, Saito S, Oikawa A, Suzuki H, Sakurai N, Shibata D, Wadano A, Sakata K, Ohta D (2006) Cytochrome P450 CYP710A encodes the sterol C-22 desaturase in Arabidopsis and tomato. Plant Cell 18:1008-1022

Nafisi M, Sønderbye IE, Hansen BG, Geu F, Eldin HHN, Nielsen MHN, Jensen NB, Li J, Halkier BA (2006) Cytochromes $\mathrm{P} 450$ in the biosynthesis of glucosinolates and indole alkaloids. Phytochem Reviews in press

Nakamura M, Satoh T, Tanaka S, Mochizuki N, Tokota T, Nagatani A (2005) Activation of the cytochrome P450 gene, CYP72C1, reduces the levels of active brassinosteroids in vivo. J Exp Bot 56:833-840

Narusaka Y, Narusaka M, Seki M, Umezawa T, Ishida J, Nakajima M, Enju A, Shinozaki K (2004) Crosstalk in the responses to abiotic and biotic stresses in Arabidopsis: analysis of gene expression in cytochrome P450 gene superfamily by cDNA microarray. Plant Mol Biol 55:327-342

Naur P, Petersen BL, Mikkelsen MD, Bak S, Rasmussen H, Olsen CE, Halkier BA (2003) CYP83A1 and CYP83B1, two nonredundant cytochrome P450 en- 
zymes metabolizing oximes in the biosynthesis of glucosinolates in Arabidopsis. Plant Physiol 133:63-72

Nawy T, Lee J-Y, Colinas J, Wang JY, Thongrod SC, Malamy JE, Birnbaum K, Benfey PN (2005) Transcriptional profile of the Arabidopsis root quiescent center. Plant Cell 17:1908-1925

Neff MM, Nguyen SM, Malancharuvil EJ, Fujioka S, Noguchi T, Seto H, Tsubuki M, Honda T, Takatsuto S, Yoshida S, Chory J (1999) BAS1: A gene regulation brassinosteroid levels and light responsiveness in Arabidopsis. Proc Natl Acad Sci USA 96:15316-15323

Nelson DR (1999) Cytochrome P450 and the individuality of species. Arch Biochem Biophys 369:1-10

Nelson DR, Kamataki T, Waxman DJ, Guengerich FP, Estabrook RW, Feyereisen R, Gonzalez FJ, Coon MJ, Gunsalus IC, Gotoh O, Okuda K, Nebert DW (1993) The P450 superfamily: update on new sequences, gene mapping, accession numbers, early trivial names of enzymes, and nomenclature. DNA Cell Biol 12:1-51

Nelson DR, Koymans L, Kamataki T, Stegeman JJ, Feyereisen R, Waxman DJ, Waterman MR, Gotoh O, Coon MJ, Estabrook RW, Gunsalus IC, Nebert DW (1996) P450 superfamily: update on new sequences, gene mapping, accession numbers, and nomenclature. Pharmacogenetics 6:1-41

Nelson DR, Schuler MA, Paquette SM, Werck-Reichhart D, Bak S (2004) Comparative genomics of Oryza sativa and Arabidopsis thaliana. Analysis of 727 chromosome P450 genes and pseudogenes from a monocot and a dicot. Plant Physiol 135:756-772

Nomura T, Kushiro T, Yokota T, Kamiya Y, Bishop GJ, Yamaguchi S (2005) The last reaction producing brassinolide is catalyzed by cytochrome P-450s, CYP85A3 in tomato and CYP85A2 in Arabidopsis. J Biol Chem 280:17873-17879

Paquette SM, Bak S, Feyereisen R (2000) Intron-exon organization and phylogeny in a large superfamily, the paralogous cytochrome P450 genes of Arabidopsis thaliana. DNA Cell Biol 19:307-317

Poulos TL, Johnson EF (2005) Structures of cytochrome P450 enzymes. In: de Montellano PRO (ed) Cytochrome P450: Structure, Mechanism, and Biochemistry third edition. Kluwer Academic/Plenum Publishers, New York, pp 87-114

Pruitt K, Tatusova T, Ostell J (2002) The reference sequence (Refseq) project. Chapter 18 in: The NCBI handbook. National Library of Medicine, National Center for Biotechnology Information, Bethesda, MD. http://ncbi.nlm.nih.gov/entrez/query.fcgi? $d b=-$ books

Redman JC, Haas BJ, Tanimoto G, Town CD (2004) Development and evaluation of an Arabidopsis whole genome Affymetrix probe array. Plant J 38:545-561

Reintanz B, Lehnen M, Reichelt M, Gershenzon J, Kowalczyk M, Sandberg G, Godde M, Uhl R, Palme K (2001) Bus, a bushy Arabidopsis CYP79F1 knockout mutant with abolished synthesis of short-chain aliphatic glucosinolates. Plant Cell 13:351-367

Rhee SY, Beavis W, Berardini TZ, Chen G, Dixon D, Doyle A, Garcia-Hernandez M, Huala E, Lander G, Montoya M, Miller N, Mueller LA, Mundodi S,
Reiser L, Tacklind J, Weems DC, Wu Y, Xu I, Yoo D, Yoon J, Zhang P (2003) The Arabidopsis Information Resource (TAIR): a model organism database providing a centralized, curated gateway to Arabidopsis biology, research materials and community. Nucl Acids Res 31:224-228

Ruegger M, Meyer K, Cusumano JC, Chapple C (1999) Regulation of ferulate-5-hydroxylase expression in Arabidopsis in the context of sinapate ester biosynthesis. Plant Physiol 119:101-110

Rupasinghe S, Baudry J, Schuler MA (2003) Common active site architecture and binding strategy of four phenylpropanoid P450s from Arabidopsis thaliana as revealed by molecular modeling. Protein Eng 16:721731

Rupasinghe S, Schuler MA (2006) Homology modeling of plant P450s. Phytochem. Reviews, (in press)

Rupasinghe S, Duan H, Schuler MA (2006) Molecular definitions of fatty acid hydroxylases in Arabidopsis thaliana. Proteins (in press)

Saito S, Hirai N, Matsumoto C, Ohigashi H, Ohta D, Sakata K, Mizutani M (2004) Arabidopsis CYP707As encode (+)-abscisic acid 8 -hydroxylase, a key enzyme in the oxidative catabolism of abscisic acid. Plant Physiol 134:1439-1449

Schalk M, Croteau R (2000) A single amino acid substitution (F363I) converts the regiochemistry of the spearmint (-)-limonene hydroxylase from a C6-to a C3-hydroxylase. Proc Natl Acad Sci USA 97:1194811953

Schoch G, Goepfert S, Morant M, Hehn A, Meyer D, Ullmann P, Werck-Reichhart D (2001) CYP98A3 from Arabidopsis thaliana is a $3^{\prime}$-hydroxylase of phenolic esters, a missing link in the phenylpropanoid pathway. J Biol Chem 276:36566-36574

Schoenbohm C, Martens S, Eder C, Forkmann G, Weisshaar B (2000) Identification of the Arabidopsis thaliana flavonoid 3'-hydroxylase gene and functional expression of the encoded P450 enzyme. Biol Chem 381:749-753

Schuhegger R, Nafisi M, Mansourova M, Petersen BL, Olsen CE, Svatos A, Halkier BA, Glawischnig E (2006) CYP71B15 (PAD3) catalyzes the final step in camalexin biosynthesis. Plant Physiol 141:12481254

Schuler MA, Werck-Reichhart D (2003) Functional genomics of P450s. Annu Rev Plant Biol 54:629-667

Shimada Y, Fujioka S, Miyauchi N, Kushiro M, Takatsuto S, Nomura T, Yokota T, Kamiya Y, Bishop GJ, Yoshida S (2001) Brassinosteroid-6-oxidases from Arabidopsis and tomato catalyze multiple C-6 oxidations in brassinosteroid biosynthesis. Plant Physiol 126:770-779

Shimada Y, Goda H, Nakamura A, Takatsuto S, Fujioka S, Yoshida S (2003) Organ-specific expression of brassinosteroid-biosynthetic genes and distribution of endogenous brassinosteroids in Arabidopsis. Plant Physiol 131:287-297

Smolen G, Bender J (2002) Arabidopsis cytochrome P450 cyp83B1 mutations activate the tryptophan biosynthetic pathway. Genetics 160:323-332 
Stewart CB, Schuler MA (1989) Antigenic crossreactivity between bacterial and plant cytochrome P-450 monooxygenases. Plant Physiol 90:534-541

Stout CD (2004) Cytochrome P450 conformational diversity. Structure 12:1921-1922

Szekeres M, Németh K, Koncz-Kálmán Z, Mathur J, Kauschmann A, Altmann T, Rédei GP, Nagy F, Schell J, Koncz C (1996) Brassinosteroids rescue the deficiency of CYP90, a cytochrome P450, controlling cell elongation and de-etiolation in Arabidopsis. Cell 85:171-182

Takahashi N, Nakazawa M, Shibata K, Yokota T, Ishikawa A, Suzuki K, Kawashima M, Ichikawa T, Shimada H, Matsui M (2005) shk1-D, a dwarf Arabidopsis mutant caused by activation of the CYP72C1 gene, has altered brassinosteroid levels. Plant J 42:13-22

Takei K, Yamaya T, Sakakibara H (2004) Arabidopsis $C Y P 735 A 1$ and $C Y P 735 A 2$ encode cytokinin hydroxylases that catalyze the biosynthesis of trans-zeatin. J Biol Chem 279:41866-41872

Thimmapuram J, Duan H, Liu L, Schuler MA (2005) Bicistronic and fused monocistronic transcripts are derived from adjacent loci in the Arabidopsis genome. RNA 11:128-138

Tian L, Musetti V, Kim J, Magallanes-Lundback M, DellaPenna D (2004) The Arabidopsis LUT1 locus encodes a member of the cytochrome P450 family that is required for carotenoid $\varepsilon$-ring hydroxylation activity. Proc Natl Acad Sci USA 101:402-407

Turk EM, Fujioka S, Seto H, Shimada Y, Takatsuto S, Yoshida S, Denzel MA, Torres QI, Neff MM (2003) CYP72B1 inactivates brassinosteroid hormones: an intersection between photomorphogenesis and plant steroid signal transduction. Plant Physiol 133:1643-1653

Urban P, Mignotte C, Kazmaier M, Delorme F, Pompon D (1997) Cloning yeast expression, and characterization of the coupling of two distantly related Arabidopsis thaliana NADPH-cytochrome P450 reductases with P450 CYP73A5. J Biol Chem 272:19176-19186

Watson CJW, Froehlich JE, Josefsson CA, Chapple C, Durst F, Benveniste I, Coolbaugh RC (2001) Local- ization of CYP86B1 in the outer envelope of chloroplasts. Plant Cell Physiol 42:873-878

Wellesen K, Durst F, Pinot F, Benveniste I, Nettesheim K, Wisman E, Steiner-Lange S, Saedler H, Yephremov A (2001) Functional analysis of the LACERATA gene of Arabidopsis provides evidence for different roles of fatty acid $\omega$-hydroxylation in development. Proc Natl Acad Sci USA 98:9694-9699

Werck-Reichhart D, Bak S, Paquette S (2002) Cytochrome P450. In: Somerville CR, Meyerowitz EM (eds) The Arabidopsis Book. Am Soc Plant Biologists Rockville, MD, doi/10.1199/tab.0028, http://www.aspb.org/ publications/arabidopsis

Winkler RG, Frank MR, Galbraith DW, Feyereisen R, Feldmann KA (1998) Systematic reverse genetics of transfer-DNA-tagged lines of Arabidopsis. Plant Physiol 118:743-750

Wittstock U, Halkier BA (2000) Cytochrome P450 CYP79A2 from Arabidopsis thaliana L. catalyzes the conversion of L-phenylalanine to phenylacetaldoxime in the biosynthesis of benzylglucosinolate. J Biol Chem 275:14659-14666

Xiao F, Goodwin SM, Xiao Y, Sun Z, Baker D, Tang X, Jenks MA, Zhou JM (2004) Arabidopsis CYP86A2 represses Pseudomonas syringae type III genes and is required for cuticle development. EMBO J. 23:29032913

Xu W, Bak S, Decker A, Paquette SM, Feyereisen R, Galbraith DW (2001) Microarray-based analysis of gene expression in very large gene families: the cytochrome P450 gene superfamily of Arabidopsis thaliana. Gene 272:61-74

Zhou N, Tootle TL, Glazebrook J (1999) Arabidopsis $P A D 3$, a gene required for camalexin biosynthesis, encodes a putative cytochrome P450 monooxygenase. Plant Cell 11:2419-2428

Zimmerman P, Hirsch-Hoffmann M, Hennig L, Gruissem W (2004) GENEVESTIGATOR. Arabidopsis microarray database and analysis toolbox. Plant Physiol 136:2621-2632 